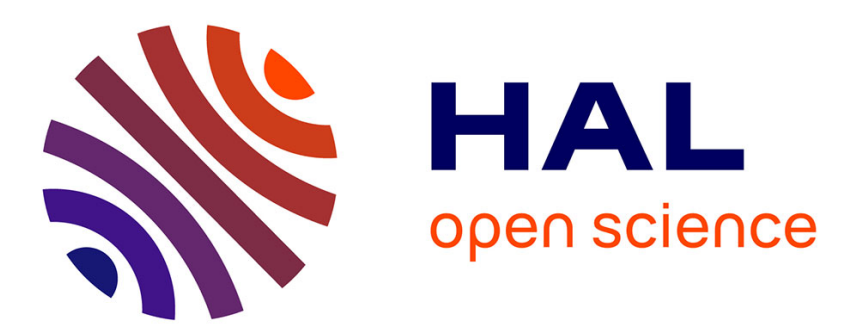

\title{
The transition from ancient to modern-style tectonics: insights from lithosphere dynamics modelling in compressional regimes
}

Jonathan Poh, Philippe Yamato, Thibault Duretz, Denis Gapais, Patrick Ledru

\section{To cite this version:}

Jonathan Poh, Philippe Yamato, Thibault Duretz, Denis Gapais, Patrick Ledru. The transition from ancient to modern-style tectonics: insights from lithosphere dynamics modelling in compressional regimes. Gondwana Research, 2021, 99, pp.77-92. 10.1016/j.gr.2021.06.016 . insu-03270651

\section{HAL Id: insu-03270651 \\ https://hal-insu.archives-ouvertes.fr/insu-03270651}

Submitted on 25 Jun 2021

HAL is a multi-disciplinary open access archive for the deposit and dissemination of scientific research documents, whether they are published or not. The documents may come from teaching and research institutions in France or abroad, or from public or private research centers.
L'archive ouverte pluridisciplinaire HAL, est destinée au dépôt et à la diffusion de documents scientifiques de niveau recherche, publiés ou non, émanant des établissements d'enseignement et de recherche français ou étrangers, des laboratoires publics ou privés. 


\section{Journal Pre-proofs}

The transition from ancient to modern-style tectonics: insights from lithosphere dynamics modelling in compressional regimes

Jonathan Poh, Philippe Yamato, Thibault Duretz, Denis Gapais, Patrick Ledru

PII:

$$
\text { S1342-937X(21)00189-1 }
$$

DOI:

$$
\text { https://doi.org/10.1016/j.gr.2021.06.016 }
$$

Reference:

GR 2607

To appear in:

Gondwana Research

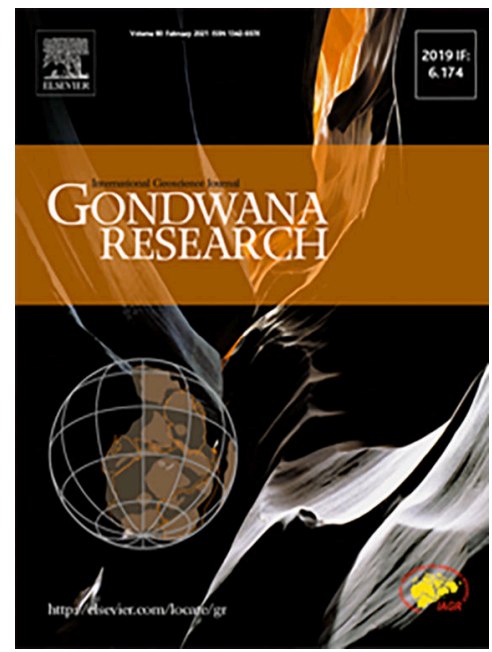

Received Date: $\quad 3$ September 2020

Revised Date: $\quad 7$ June 2021

Accepted Date: $\quad 21$ June 2021

Please cite this article as: J. Poh, P. Yamato, T. Duretz, D. Gapais, P. Ledru, The transition from ancient to modern-style tectonics: insights from lithosphere dynamics modelling in compressional regimes, Gondwana Research (2021), doi: https://doi.org/10.1016/j.gr.2021.06.016

This is a PDF file of an article that has undergone enhancements after acceptance, such as the addition of a cover page and metadata, and formatting for readability, but it is not yet the definitive version of record. This version will undergo additional copyediting, typesetting and review before it is published in its final form, but we are providing this version to give early visibility of the article. Please note that, during the production process, errors may be discovered which could affect the content, and all legal disclaimers that apply to the journal pertain.

(c) 2021 International Association for Gondwana Research. Published by Elsevier B.V. All rights reserved. 


\title{
The transition from ancient to modern-style tectonics: insights from lithosphere dynamics modelling in compressional regimes
}

\author{
Jonathan Poh ${ }^{a, *}$, Philippe Yamato ${ }^{a, b}$, Thibault Duretz ${ }^{a}$, Denis Gapais ${ }^{a}$, Patrick Ledru ${ }^{c}$ \\ aUniv Rennes, CNRS, Géosciences Rennes, UMR 6118, 35000 Rennes, France \\ ${ }^{b}$ Institut Universitaire de France (IUF), France \\ ' Université de Lorraine, GeoRessources 2, rue du Doyen Marcel Roubault TSA 7060554518 \\ Vandoeuvre-lés-Nancy cedex FRANCE
}

\begin{abstract}
Orogens are traditionally classified according to their tectonic style. Paleoproterozoic tectonics is referred to as "ancient-style tectonics" while Proterozoic tectonics is referred to as "modern-style tectonics". Ancient-style tectonics is characterised by distributed vertical structures and low topography gradients, often associated with diapirism and partial melting. In contrast, modern-style tectonics involve prominent strain localisation and the formation of thrusts, nappes and high topographic gradients. However, the parameters controlling the transition from ancient to modern-style tectonics are poorly understood. To quantify this transition, a combination of 1D and 2D high resolution lithospheric-scale thermo-mechanical models was conducted. The parameters controlling the strength of the lithosphere (i.e., Moho temperature, strain rate, crustal rheology, crustal radiogenic heat production and role of shear heating) were investigated in detail. Our results show that tectonic style is controlled by the maximum of crustal strength (shear stress). Modern-style tectonics is observed to occur when the maximum of crustal strength is greater than $300 \mathrm{MPa}$. At the opposite, a maximum crustal strength lower than $300 \mathrm{MPa}$ leads to ancient style tectonic structures. Therefore, crustal rheology, temperature and background strain rate significantly influence the transition from ancient to modern-style tectonics. Shear heating remains a key factor in promoting strain localisation in modern-style tectonics. Crustal radiogenic heat production has a moderate influence by increasing/decreasing the tendency for faulting within the crust. This crustal strength criterion also provides an excellent fit for a second potential proxy: a localisation
\end{abstract}

\footnotetext{
${ }^{*}$ Corresponding author

Email address: jonathanpoh87@gmail.com(Jonathan Poh)
} 
criterion of ca. $225^{\circ} \mathrm{C}$. These two proposed proxies can be used interchangeably to predict the transition from ancient to modern-style tectonics.

Keywords: rheology of the lithosphere, shear heating, modern tectonics, ancient tectonics, strength of the lithosphere, strain localisation

\section{Introduction}

\subsection{Two different tectonic styles across geological times}

Tectonic styles on Earth have evolved throughout geological time. Field observations from Archean and Paleoproterozoic cratons show specific structural and metamorphic features (e.g., Cagnard et al., 2011; Chardon et al., 2009; 2018). Widespread structures observed at the upper parts of the crust present steep cleavages and plunging stretching lineations, and are associated with low metamorphic grades up to greenshist facies (see Gapais et al., 2009; Chardon et al., 2009). The exhumed lower crust is marked by widespread distributed strains with vertical stretching lineations and is often associated with partially molten supracrustal rocks reaching, in some places, granulite metamorphic facies conditions (Pressure $(P$ ) $\leq 1 \mathrm{GPa}$, Temperature $(T) \leq 850^{\circ} \mathrm{C}$, Bouhallier et al., 1995; Cagnard et al., 2006, 2007, 2011; Chardon et al., 2009; Choukroune et al., 1995; Gapais et al., 2005, 2014). One important characteristic is that no major jumps in metamorphic facies conditions has been observed between the different tectonic units. This is seen from the retrogression of Archean granulite facies assemblages towards the Paleoproterozoic amphibolite facies assemblages from most Archean belts and Paleoproterozoic belts such as the $3.0 \mathrm{Ga}$ Archean East Dharwar Craton (e.g., Bouhallier et al., 1995; Chardon et al., 2011, 2009), the 1.69 Ga Terre Adelie Craton in Antarctica (Gapais et al., 2008), the Thompson Nickel Belt in Canada (Gapais et al., 2005, 2014), and in the $1.9 \mathrm{Ga}$ Paleoproterozoic Svecofennides (e.g., Cagnard et al.,2007). Furthermore, it is also argued that the downward and lateral motions in the upper and lower portions of the crust, respectively, occur in a lithosphere that consists of a mechanically weak crust and mantle (i.e., crème brûlée lithosphere; Burov et al., 2006; Burov, 2011, and Fig. 1A left), due to the presence of a hot thermal gradient. Previous numerical studies indicate that these deformation features are caused by 
plutonism, capable of generating lateral flows perpendicular to the direction of shortening while being marked with low topography (e.g., Duclaux et al., 2007; Cruden et al., 2006; Rey and Houseman, 2006). This tectonic style can be classified as ancient-style tectonics as these deformation features have been observed.

In contrast, modern-style tectonics (i.e., Phanerozoic), is characterised by different structural and metamorphic features (Gapais et al., 2009, and references therein). Deformation styles are characterised by well-defined rock units separated by major shear zones. Some rock units now exhumed at the surface, can show in some places, high pressure metamorphic conditions $\left(P \geq 1.0 \mathrm{GPa}, T \geq 500^{\circ} \mathrm{C}\right)$. These exhumed blueschist or ecolgite facies rocks are directly related to the development of major shear zones (i.e., lithospheric-scale thrusts, normal faults and nappe stacks) associated with the generation of high topography. These modern-style tectonics are generally linked to colder and mechanically strong lithospheres (jelly sandwich in Jackson (2002) and Fig. 1A, right) to be able to support topography and macrostructures (Burov et al., 2006). These structural and metamorphic features are commonly documented in modern-style orogens as seen in the ca. 50 Ma Himalayas (e.g., de Sigoyer et al., 2004), in the ca. 35 Ma European Alps (e.g., Schmid et al., 2017), and in the ca. 5 Ma Taiwan Orogeny (e.g., Yamato et al., 2009).

From a geodynamical point of view, the transition from ancient to modern-style tectonics is associated with the gradual evolution from 'rips and plumes' tectonics towards modern plate tectonics (e.g., Gerya, 2019a; Palin et al., 2020; Palin and Santosh, 2020; Brown et al., 2020, and references therein). Several proxies have been discovered to track the evolution of this transition. The first proxy relates to the distribution of metamorphic rocks throughout time (e.g., Brown, 2006; Brown and Johnson, 2018; Holder et al., 2019). A diagnostic feature for modern plate tectonics is the presence of a paired distribution of metamorphic temperatures and pressures (Brown, 2006; Miyashiro, 1961). The statistical analysis determined a non-gaussian distribution from $2.2-1.4 \mathrm{Ga}$, evolving towards a distinctive bimodal distribution in rock samples after 1.4 Ga (Holder et al., 2019). The analysis also demonstrated a distinct divergence of low and high metamorphic T/P ratio in metamorphic rocks, reflecting the secular cooling of the Earth. Additionally, a similar thermal divergence can be measured in magma temperatures from greenstone belts and komatiites at $2.5-2.0 \mathrm{Ga}$ (Condie et al., 2016). Previous geochemistry studies on the Earth's 
mantle and rocks formed determined that the lithosphere have undergone irreversible geochemical differentiation (e.g., Anderson, 2002; Martin and Moyen, 2002; Tang et al., 2016; Johnson et al., 2019; Nebel et al., 2018; Capitanio et al., 2019; Johnson et al., 2019). For instance, the presence or absence of plagioclase within tonalite-trondhjemite-granodiorite rocks (TTGs) provides a proxy for slab melting depth and geothermal gradient (Martin and Moyen, 2002). Martin and Moyen (2002) indicate that the secular cooling of the lithosphere (i.e., a reduction of the radiogenic heat production produced in crust and heat flow output from the mantle) increased the melting depth where plagioclase is stable. This secular cooling is also linked to the changes in crustal chemistry observed in the transition from Archean granitoid intrusions of TTGs to potassic (K) granite suites (Nebel et al., 2018). The source for the felsic material originates from these 'asymmetric drips' of the melting lithospheric mantle. Thermo-mechanical models conducted in Nebel et al. (2018) and Capitanio et al. (2019) indicate that these melts produce hot thermal-depth gradients (up to $30^{\circ} \mathrm{C} . \mathrm{km}^{-1}$ ) that create a feedback loop of concentrated melting process that strengthen the lithospheric mantle. The injection of more felsic melts into the mantle through localised episodes of 'proto-subduction' could explain the changes in the felsic composition of the TTGs, increasing crustal strength (Hawkesworth and Brown, 2018; Johnson et al., 2019; Nebel et al., 2018; Rey et al., 2014; Rey and Coltice, 2008). Additionally, $\mathrm{MgO}$ content in igneous and metamorphic rocks marks the transition of Archean upper crust from highly mafic at $3.0 \mathrm{Ga}$ to felsic at $2.5 \mathrm{Ga}$ (Tang et al., 2016). Therefore, the secular cooling of the lithosphere is strongly associated with the critical parameters that control the resultant tectonic style (Lenardic, 2018).

Recent field studies in the Paleoproterozoic Lapland Granulite belt and in the Sveconfennian domain in Finland (Cagnard et al., 2011, and references therein) provide evidence that the transitional tectonics regime feature consists in a combination of modern and ancient tectonic modes, according to the nature (strength) of involved converging plates and associated thermal states (Cagnard et al., 2011; Lenardic, 2018). Field observations indeed show a widespread of vertical thrusts formed due to a regional-scale horizontal shortening (i.e., ancient-style tectonics) associated with metamorphism in sediments that reached $P>600 \mathrm{MPa}$ and $T>750^{\circ} \mathrm{C}$ (Cagnard et al., 2011). The occurrence of high-grade shear zones (i.e., modern-style structures), which is coeval with widespread partial melting of the 
sediments at low pressure is also observed. Lastly, retrograde metamorphism analysis by Cagnard et al. (2011) indicates a protracted exhumation activity (ca. 20 30 Myrs) that is interpreted as the result of distributed erosion process (i.e., ancientstyle tectonics). Therefore, the structural and metamorphic evolution observed in the Lapland Granulite belt suggests that different tectonic styles can coexist. This change of tectonic style is in contrast to the neighbouring Sveconfennian domain which presents deformation features in agreement with ancient-style tectonics (Cagnard et al., 2007; Choukroune et al., 1995) while it is of similar age (1.9 - 1.89 Ga). This corresponds to the age of the unequivocal oldest subduction-related high pressure eclogite of $2.1 \mathrm{Ga}$ (see Palin et al., 2020); a potential age of the transition between modern and ancient-style tectonics. The period of the first occurrence of plate tectonics evidence remains debatable even though decades-worth of published studies and several ages ranging from 4.0 Ga Hadean to 1.0 Ga Neoproterozoic are proposed (Palin et al., 2020; Palin and Santosh, 2020). The latest proposed age for the first evidence of global plate tectonics is $3.0 \mathrm{Ga}$ as reviewed in Palin and Santosh (2020). This proposed age corresponds to earlier formations of supercontinents such as ca. 3.0 Ga Ur and ca. 2.7 - 2.5 Ga Kenorland (Rogers and Santosh, 2004).

\subsection{Strength of the lithosphere and parameters to test}

Strength of the lithosphere depends on four main parameters that control the location of coupling/decoupling horizons within the lithosphere and the magnitude of stresses (Fig. 1A): strain rate, temperature, crustal radiogenic heat production, and material properties. Using numerical models, it is possible to test a broad range of strength configurations of the lithosphere to determine what causes the transition from ancient to modern-style tectonics and to investigate the following questions:

1. What parameter controls the deformation at the crust and the lithospheric mantle?

2. Can a transition from ancient to modern-style tectonics be identified and quantified?

3. What controls the occurrence of localised deformation?

The general consensus states that the thermal state of the lithosphere dictates the resultant tectonic style. Numerical models suggest that transitional tectonics occurred 
at mantle temperature up to $200^{\circ} \mathrm{C}$ higher than today and was triggered by the generation of continental crust and the stabilisation of cratons (e.g., Sizova et al., 2010, 2015; Perchuk et al., 2018). However, a recent thermo-mechanical study indicated that the shortening rate, which can vary over several orders of magnitude, also plays an important role (Poh et al., 2020). High shortening rates $\left(\dot{\varepsilon}_{B G}>1 \times 10^{-15} \mathrm{~s}^{-}\right.$ $\left.{ }^{1}\right)$ favours the formation of asymmetric deformation zones (i.e., modern-style tectonics) while low shortening rates $\left(\dot{\varepsilon}_{B G}<1 \times 10^{-15} \mathrm{~s}^{-1}\right)$ favour the development of distributed deformation zones and vertical structures (i.e., ancient-style tectonics). In Poh et al. (2020), the study was conducted at a high crustal radiogenic heat production $\left(H_{R}=2.0 \mu \mathrm{W} \cdot \mathrm{m}^{-3}\right)$ to mimic conditions during the Precambrian. Modernstyle lithospheres however, are considered to have lower crustal radiogenic heat production values (Condie and Benn, 2006) or to present a localised distribution of high heat producing rocks (e.g., Faccenda et al., 2008). Furthermore, shear heating has also been identified as a mechanism of crustal and lithosphere-scale shear localisation (e.g., Thielmann and Kaus, 2012; Duretz et al., 2014; Kiss et al., 2019; Auzemery et al. 2020). It is thus important to understand the role of shear heating in the transition between ancient and modern-style tectonics.

In this contribution, a series of $2 \mathrm{D}$ numerical models implying a lithosphere subjected to a compressive regime have been performed to explore a wide range of parameters: strain rate, Moho temperature, crustal rheology, radiogenic heat production values. Each of these parameters affect the strength of the crust. In order to identify the parameters that control the transition between the different tectonic styles. 3 main factors are particularly studied from our models: (i) the distribution of the deformation and shear zone generation at the upper parts of the crust but also within the lithospheric mantle, (ii) the topography evolution and its range of topography, and (iii) the distribution of the $P-T$ field. The impact of shear heating on each tectonic style was also investigated. 


\section{Numerical Approach}

\subsection{Governing equations}

Two-dimensional (2D) thermo-mechanical models were used to simulate the shortening of a visco-elasto-plastic continental lithosphere. The 2D finite-difference, marker- in-cell code (MDoodz; Duretz et al., 2016) used in this investigation solves the equations of momentum, mass conservation and heat, which are formulated as:

$$
\begin{gathered}
\frac{\partial \tau_{i j}}{\partial x_{j}}-\frac{\partial P}{\partial x_{i}}=-\rho^{\mathrm{eff}} g_{i}, \\
\frac{\partial v_{i}}{\partial x_{i}}=0, \\
\rho^{\mathrm{eff}} C_{p}^{\mathrm{eff}} \frac{d T}{d t}=\frac{\partial}{\partial x_{i}} k \frac{\partial T}{\partial x_{i}}+H_{R}+H_{S}+H_{L}+H_{A},
\end{gathered}
$$

$$
\text { where } \tau_{i j} \text { correspond to the deviatoric stress tensor, } P \text { is total pressure, } v_{i} \text { represents }
$$
the velocity vector components, $\rho$ is the density, $T$ is the temperature, $C_{p}$ is the specific heat capacity, and $k$ is the thermal conductivity. In Eqn. 3, the rocks' effective density ( $\left.\rho^{\text {eff }}\right)$ and heat capacity $\left(C_{p}^{\text {eff }}\right)$ are only considered when the rock reach partial melting conditions (see Sec. 2.1.2). The heat equation includes the effect of radiogenic heat production $\left(H_{R}\right)$, latent heat of production or consumption $\left(H_{L}\right)$, adiabatic heat $\left(H_{A}\right)$, and shear heating $\left(H_{S}\right)$. The subscript indexes $i$ and $j$ denote the Einstein notation for spatial directions.

The Boussinesq approximation is applied to the models (in Eqn. 2). This approximation assumes that the impact of volume changes is neglected.

Shear heating $\left(H_{S}\right)$ is evaluated by the deviatoric stress and the dissipative part of the strain rate tensor, which is formulated as:

$$
H_{S}=\left(\dot{\varepsilon}_{x x}-\dot{\varepsilon}_{x x}^{\mathrm{el}}\right) \tau_{x x}+\left(\dot{\varepsilon}_{z z}-\dot{\varepsilon}_{z z}^{\mathrm{el}}\right) \tau_{z z}+2\left(\dot{\varepsilon}_{x z}-\dot{\varepsilon}_{x z}^{\mathrm{el}}\right) \tau_{x z}
$$


$\rho=\rho_{0}^{\text {solid }}\left(1-\alpha\left(T-T_{0}\right)\right)\left(1+\beta\left(P-P_{0}\right)\right)$

214 where $\rho_{0}^{\text {solid }}$ is the reference density, $\alpha$ is the thermal expansion, and $\beta$ is the thermal

\subsubsection{Maxwell visco-elasto-plastic rheology}

The lithosphere is considered as a Maxwell visco-elasto-plastic medium, which assumes that viscous, plastic, and elastic deformations occur concurrently for a given value of deviatoric stress ( $\tau_{i j}$, see also Yamato et al., 2019, for more details). The deviatoric strain rate tensor $\left(\dot{\varepsilon}_{i j}\right)$ is then formulated as:

$\dot{\varepsilon}_{i j}=\dot{\varepsilon}_{i j}^{\mathrm{vis}}+\dot{\varepsilon}_{i j}^{\mathrm{el}}+\dot{\varepsilon}_{i j}^{\mathrm{pl}}$

The effective creep viscosity ( $\left.\eta^{\text {eff }}\right)$ is computed by following a thermally activated power law that represents the dislocation creep deformation mechanism (e.g., Chopra and Paterson, 1984; Hansen and Carter, 1983; Ranalli, 1995, 1997). $\eta^{\text {eff }}$ is dependent on the second invariant of the creep strain rate tensor, $\dot{\varepsilon}_{\mathrm{II}}^{\mathrm{vis}}$ and is computed as:

$\eta^{\mathrm{eff}}=\frac{\tau_{\mathrm{II}}}{2 \dot{\varepsilon}_{\mathrm{II}}^{\mathrm{vis}}}=F A^{-\frac{1}{n}} \dot{\varepsilon}_{\mathrm{II}}^{\mathrm{vis}}\left(\frac{1}{n}-1\right) \exp \frac{Q}{n R T} \exp \frac{a M}{n}$

where $n, A$, and $Q$ are material parameters derived from laboratory experiments (see Table 1), $F=\frac{2^{(1-n) / n}}{3^{(n-1) / 2 n}}$ is the dimension coefficient for triaxial experiments, $\tau_{\text {II }}$ is the second invariant of the deviatoric stress tensor, $R=8.314 \mathrm{~J}_{\mathrm{mol}}{ }^{-1}$ is the gas constant, $T$ is the temperature (in $\mathrm{K}$ ), $a$ is a melt-weakening factor, and $M$ is the melt fraction (e.g., Hirth and Kohlstedt, 2004).

Pressure-dependent plasticity is modelled using a Drucker-Prager yield surface, and the yield stress is formulated as follows:

$\sigma^{\text {yield }}=C \cos \phi+P \sin \phi$

where $\varphi$ and $C$ are the friction angle and cohesion, respectively (see Table 1).

Density $(\rho)$ is assumed to be $P-T$ dependent seen as:

compressibility (see Table 1$) . T_{0}(=273.15 \mathrm{~K}), P_{0}\left(=10^{5} \mathrm{~Pa}\right)$, and $\rho_{0}$ correspond to reference temperature, pressure, and density, respectively.

\subsubsection{Partial melting}


Latent heat $\left(H_{L}\right)$ becomes important when partial melting or crystallisation occurs.

In the case of melting, $H_{L}$ operates as a heat sink $\left(H_{L}<0\right)$, while crystallisation induces a heat source $\left(H_{L}>0\right)$. When using a single-phase formulation, the effects of partial melting can be approximated by: (i) reduction in density with increasing melt fraction (ii) lowering the effective viscosity (see Eqn. 6), and (iii) thermal effects due to melting and crystallisation processes. The volumetric fraction of melt is assumed to increase linearly with temperature, according to these relationships (Burg and Gerya, 2005; Gerya and Yuen, 2003):

226

$M=0$, at $T \leq T_{\text {solidus }}$

$M=\frac{T-T_{\text {solidus }}}{T_{\text {liqudus }}-T_{\text {solidus }}}$, at $T_{\text {solidus }}<T<T_{\text {liquidus }}$

$M=1$, at $T \geq T_{\text {liqudus }}$

where $T_{\text {solidus }}$ and $T_{\text {liquidus }}$ are the wet solidus and dry liquidus temperatures of the considered rock, respectively (see Table 1 for equations). The volumetric fraction of melt $(M)$ influences the effective density $\left(\rho^{\text {eff }}\right)$ of the partially molten rocks as follows:

$\rho^{\mathrm{eff}}=\rho\left(1-M+M \frac{\rho_{0}^{\text {molten }}}{\rho_{0}^{\text {solid }}}\right)$

231

232

233

234

where $\rho_{0}^{\text {solid }}=\rho_{0}$ and $\rho_{0}^{\text {molten }}$ are liquid densities (see Table 1).

Other processes associated with partial melting, such as solid-melt segregation and melt extraction, are neglected. This assumption is discussed further in Section 4.4. The effect of latent heating due to equilibrium melting or crystallisation is included implicitly by increasing the effective heat capacity $\left(C_{\mathrm{p}}^{\mathrm{eff}}\right)$ and the thermal expansion ( $\left.\alpha^{\text {eff }}\right)$ of the partially crystallised molten rocks $(0<M<1)$ following Burg and Gerya (2005). $Q_{L}$ is the latent heat of melting of the considered rocks. 
240

$$
\begin{gathered}
C_{\mathrm{P}}^{e f f}=C_{\mathrm{P}}+Q_{L}\left(\frac{\partial M}{\partial T}\right)_{P} \\
\alpha^{\mathrm{eff}}=\alpha+\rho \frac{Q_{L}}{T}\left(\frac{\partial M}{\partial P}\right)_{T}
\end{gathered}
$$

Advection of composition, temperature, strain, and stress fields is carried out in a Lagrangian manner using the particle-in-cell method. Particles are advected at each time step in an explicit manner using a $1^{\text {st }}$ order in time and $4^{\text {th }}$ order in space RungeKutta scheme. The Courant condition ratio is set at 0.3 for all 2D numericalmodels.

\subsection{Model setup}

The numerical model consists of 800 (horizontal) by 330 (vertical) uniformly distributed nodes, which gives the physical dimensions of $400 \mathrm{~km}$ by $165 \mathrm{~km}$ for the model box and results in a grid spacing of $500 \mathrm{~m}$ (Fig. 1B). The top of the model is a free surface (Duretz et al., 2016). The geological model consists of a rectangular 30 $\mathrm{km}$ thick crust that is subdivided into two homogeneous components: a $2.5 \mathrm{~km}$ sedimentary layer over a $27.5 \mathrm{~km}$ granitic crust. This value is chosen as an average crustal thickness. The initial thickness of the crust is then free to thicken during the simulation, subjected to boundary conditions and the material properties used. This study is thus restricted to the case of a homogeneous visco-elasto-plastic crust. A circular sedimentary inclusion (weak seed) with a diameter of $2 \mathrm{~km}$ was placed at a depth of $8.5 \mathrm{~km}$ and at $x=-10 \mathrm{~km}$ to initiate the deformation. Rheological laws used in the models and their thermal parameters are presented in Table 1.

To simulate a compressive regime, a fixed velocity $(v)$ corresponding to an average strain rate $\left(\dot{\varepsilon}_{\mathrm{BG}}\right)$ normal to the lateral boundaries is imposed. Material inflow is compensated by imposing a normal outflow at the bottom boundary ( $\left.v_{\text {bottom }}\right)$, thus satisfying the mass conservation in the whole model domain. Since the size of the model and applied shortening velocity remains constant throughout the simulation, the corresponding average strain rate (i.e., $\dot{\varepsilon}_{\mathrm{BG}}$ ) applied at the boundaries is also constant. The 2D parametric study is conducted over a wide range of initial geotherms $\left(T_{\text {Moho }}=850^{\circ} \mathrm{C}\right.$ to $\left.550^{\circ} \mathrm{C}\right)$ and shortening rates $\left(\dot{\varepsilon}_{\mathrm{BG}}=1 \times 10^{-14} \mathrm{~s}^{-1}\right.$ to $2 \times 10^{-}$ $16 \mathrm{~s}^{-1}$ ) to cover a wide range of lithospheric strength configurations. The initial 
geotherm was computed using thermal parameters (presented in Table 1) and a fixed temperature boundary of $1330^{\circ} \mathrm{C}$ at the base of an adiabatic asthenosphere. The temperature field was obtained by solving the heat equation until steady state and by varying the thickness of the lithosphere until the desired Moho temperature was reached. This constrains the initial thickness of the lithosphere.

Fig. 1A shows the yield strength envelopes and geotherms corresponding to the end-member tectonic models at initial conditions. These models were obtained by considering a combination of temperature field and strain rate $\left(T_{\text {Moho }}\right.$ and $\dot{\varepsilon}_{\mathrm{BG}}$ values from left to right in Fig. $1 \mathrm{~A}:\left[750^{\circ} \mathrm{C}, 1.0 \times 10^{-15} \mathrm{~s}^{-1}\right]$, $\left.\left[550^{\circ} \mathrm{C}, 1.0 \times 10^{-14} \mathrm{~s}^{-1}\right]\right)$.

\section{Results}

For the initial 2D parametric study of 16 numerical simulations, two governing parameters are considered: shortening rates $\left(\dot{\varepsilon}_{\mathrm{BG}}\right)$ and Moho temperature ( $\left.T_{\text {Moho }}\right)$. The summary of these experiments are shown in Fig. 2 and Supplementary Data, Fig. S1. Two main deformation styles can be characterised. They can be presented using two models and represent the ancient and modern-style tectonics; corresponding to the parameters marked as by red and blue squares (in Figs. 2, 3 and 4).

\subsection{End-member tectonic styles and reference models}

The reference model that generated ancient-style tectonics has an initial Moho temperature of $750^{\circ} \mathrm{C}$ and a background strain rate of $1 \times 10^{-15} \mathrm{~s}^{-1}$ (Fig. 3A). After ca. $320 \mathrm{~km}$ of horizontal shortening, the Moho remained flat. In the upper portions of the crust, localised strain area within sedimentary cusps are vertically oriented. Additionally, regions of high viscosity beneath the sedimentary cusps at $25 \mathrm{~km}$ depth are formed and facilitate strain localisation ( $\eta_{\mathrm{eff}}>10^{22}$ Pa.s in $x=-75 \mathrm{~km}$ and $+45 \mathrm{~km}$ in Fig. 3A). The evolution of topography depicts two deformation stages (buckling and cusping) expressed as a periodic sequence of crests and troughs (Fig. 4A). The maximum topographic range (i.e., the difference between the maximum and the minimum of topography) is $2.0 \mathrm{~km}$ (Fig. 4A) and is in agreement with the values expected until Neoarchean (Rey and Coltice, 2008). Additionally, horizontal isotherms and isobars indicates an absence of major reverse metamorphic pressure breaks. When compared to the rest of the parametric study, this trend of distributed deformation at the upper parts of the crust and minimal strain localisation of the 
lithospheric mantle (i.e., flat Moho) continues in models with high Moho temperatures $\left(T_{\text {Moho }} \geq 650^{\circ} \mathrm{C}\right) . \mathrm{A}+100^{\circ} \mathrm{C}$ increase to $T_{\text {Moho }}=850^{\circ} \mathrm{C}$ leads to the formation of wellestablished crustal convection in the lower parts of the crust. The lateral thickness of the buried sediments has decreased and the formation of sedimentary cusps begins. Rapid crustal convection with limited burial of the sedimentary layer occurs when strain rate is decreased by an order of magnitude $\left(\dot{\varepsilon}_{\mathrm{BG}}=2.0 \times 10^{-16} \mathrm{~s}^{-1}\right)$. An order of magnitude increase in strain rate $\left(\dot{\varepsilon}_{\mathrm{BG}}=1.0 \times 10^{-14} \mathrm{~s}^{-1}\right)$ leads to the generation of undeformed zones marked by high viscosity triangular wedges ( $\eta \geq 10^{23} \mathrm{~Pa}$.s) in the upper parts of the crust and increases strain localisation in the lithospheric mantle (i.e., from flat Moho to slightly uneven Moho).

The reference model for modern-style tectonics corresponds to an initial Moho temperature of $550^{\circ} \mathrm{C}$ and a background strain rate of $1 \times 10^{-14} \mathrm{~s}^{-1}$ (Fig. 3B). After ca. $320 \mathrm{~km}$ of horizontal shortening, the lithospheric mantle shows asymmetric burial of the Moho reaching ca. $100 \mathrm{~km}$ depth. This burial depth reached by the lithospheric mantle indicates that subduction initiated. The upper part of the crust is affected by multiple thrusts (Fig. 3B). Accumulated strain maps indicate the formation of shear zones within both the crust and the lithospheric mantle. The evolution of the topography shows a three-stage deformation evolution: (i) Initial buckling of the lithospheric mantle that corresponds to the first topographic high occurring during the first $60 \mathrm{~km}$ of horizontal shortening; (ii) shearing of the lithospheric mantle associated to a decrease of the topography; (iii) thrusting of the mantle and the upper parts of the crust and formation of periodic topographic crests and troughs with a wavelength of $50 \mathrm{~km}$ after $240 \mathrm{~km}$ of horizontal shortening (Fig. 4B). The maximum topographic range achieved in this model after $80 \%$ of horizontal shortening is $13.4 \mathrm{~km}$. When compared to the rest of the parametric study, similar deformation style persists in models with low Moho temperatures $\left(T_{\text {Moho }}=550^{\circ} \mathrm{C}\right)$ for most of the strain-rates and one at $T_{\text {Moho }}=650^{\circ} \mathrm{C}$ and $\dot{\varepsilon}_{\mathrm{BG}}=1.0 \times 10^{-14}$. When $T_{\text {Moho }}$ increases, deformation of the lithospheric mantle decrease and lithospheric-scale shear zones and uneven Moho are progressively replaced by a flat Moho. However, the occurrence of undeformed zones marked by high viscosity triangular wedges (i.e., Pop-downs; $\eta \geq 10^{23}$ Pa.s) at the upper parts of the crust still persist. The amount of deformation at the upper parts of the crust decreased with reduced strain rate, concurring with observations in the discussion of the ancient-style tectonics reference model. 
The 2D parametric study confirms that the magnitude of the strain rate controls the type of crustal deformation feature as shown by Poh et al. (2020). The cusping of the buried sedimentary rocks occurs at low strain rates $\left(\dot{\varepsilon}_{\mathrm{BG}} \leq 1 \times 10^{-15} \mathrm{~s}^{-1}\right)$, whereas thrusts of the upper parts of the crust is favoured at high strain rates $\left(\dot{\varepsilon}_{\mathrm{BG}} \geq 2 \times 10^{-15} \mathrm{~s}^{-}\right.$ 1). The intensity of deformation of the lithospheric mantle is suggested to be significantly controlled by Moho temperatures instead of strain rates. These reference models are then subjected to further tests (i.e., crustal rheology, crustal radiogenic heat production, and the role of shear heating).

\subsection{Effect of shear heating}

Figs. 5 and 6 present the two reference models with and without the activation of shear heating, respectively. The ancient-style reference model remains similar despite neglecting shear heating (Fig. 5B). The upper parts of the crust displayed similar distributed cusping of the sedimentary layer and homogeneous thickening of the crust with a flat Moho. The thickened crust presents a thick lower parts of the crust bounded by the $700^{\circ} \mathrm{C}$ isotherm.

The effects of shear heating are more important for the modern-style tectonics model (Fig. 6B). Indeed, in mechanically strong lithospheres, conditions for strain localisation by shear heating are easily met (Fig. 1B). Shear zone formation within the lithospheric mantle leads to a decrease of the viscosity (from $\eta_{\mathrm{eff}}=10^{23} \mathrm{~Pa}$.s to $10^{21}$ Pa.s). The upper part of the crust also exhibits prominent thrusts $(x=+150 \mathrm{~km}$ in Fig. 6A, top). When shear heating is neglected, strain localisation does not occur within the lithospheric mantle (i.e., subduction initiation fails, Fig. 6B). The upper parts of the crust exhibits buckling with the generation of overpressured area (> $500 \mathrm{MPa}$ at ca. $15 \mathrm{~km}$ depth). The brittle domains of both the crust and mantle show numerous frictional-plastic shear bands.

\subsection{Effect of crustal rheology}

In addition to the variation of shortening rate and geotherms, crustal strength is also controlled by the composition of the lithosphere (Fig. 1A). The crustal rheology dictates the depth of the brittle-ductile transition (e.g., Fig. 1A left and right), which subsequently affects the resulting deformation (e.g., Yamato et al., 2008; Duretz and Gerya, 2013a; Liao and Gerya, 2017). The crustal rheology applied to the 2D parametric study (Fig. 3 and Supplementary Data, Fig. S1) is Dry Westerly Granite 
(Hansen and Carter, 1983). The role of the rheology is tested by varying the crustal lithology and its associated flow law parameters (i.e., Dry Quartzite (Ranalli, 1995, 1997) and Dry Felsic Granulite (Ranalli, 1995)) on the two reference models (Figs. 7 and 8). Models with a weaker crust (i.e., using Dry Quartzite) are shown in Figs. 7A and 7B; whereas the models with a stronger crust (i.e., using dry felsic granulite) are presented in Figs. 8A and 8B.

For the ancient-style tectonic model (Fig. 7A), the presence of a weak crust leads to a distributed crustal deformation. Burial of the sedimentary layer by cusping is less pronounced ( $<10 \mathrm{~km}$ depth) compared to the reference model in which the cusps reached ca. $15 \mathrm{~km}$ depth for a similar amount of shortening (Fig. 3A). Most tectonic structures in the buried sediments remain oriented vertically as in the reference model. However, strain is more distributed. Convection of the partially molten parts of the lower parts of the crust is observed as in the reference model. The topographic range reduces from $2.0 \mathrm{~km}$ to $1.4 \mathrm{~km}$. When applying a weak crustal rheology to the modern-style tectonic model, Pop-downs at the upper parts of the crust are formed. The sedimentary layer is buried periodically (Fig. 7B). The lithospheric mantle experienced a downward deflection reaching $100 \mathrm{~km}$ depth which is accompanied by the thickening of the crust at ca. $100 \mathrm{~km}$ depth in the middle. The topographic range increased (from $13.4 \mathrm{~km}$ to $15.4 \mathrm{~km}$ ) due to the decoupling of the upper parts of the crust and the lithospheric mantle (strain is localised here instead).

The use of a felsic granulite rheology generated changes in deformation patterns for both tectonic models (Fig. 8A and B). In Fig. 8A, the ancient-style tectonic model with a stronger crust depicts the appearance of reverse faults in the upper parts of the crust while maintaining an undeformed lithospheric mantle. Although cusping of sediments still occurs, the generation of dipping faults suggests a transition from a distributed deformation to a localised and asymmetric deformation. Crustal convection is not present at the lower part of the crust. The topographic range has increased from $2.0 \mathrm{~km}$ to $4.5 \mathrm{~km}$. Applying a stronger crust to the modern-style tectonic model generates deformation features similar to the modern-style tectonics reference model (in Fig. 3B and 8B). Thrusts occurs in both upper parts of the crust and lithospheric mantle. The only difference is the presence of an upward deflection of the lithospheric mantle (Fig. 8B), which greatly increases topographic range (from $13.4 \mathrm{~km}$ to ca. 
formation of modern-style deformation features in the model (i.e., faults and thrusts at the upper parts of the crust and strain localisation at the lithospheric mantle).

\subsection{Effect of crustal radiogenic heat production $\left(H_{R}\right)$}

The value of $H_{R}$ used for the crust and sedimentary layer in all the abovedescribed models was kept constant $\left(2.0 \mu \mathrm{W} \cdot \mathrm{m}^{-3}\right)$. To address the large range of possible $H_{R}$ values from previous compilations (e.g., up to $4.2 \mu \mathrm{W} . \mathrm{m}^{-3}$ in Mareschal and Jaupart, 2013; Jaupart et al., 2016; Goes et al., 2020), the median value was selected. Two additional values were also tested (Moderate $H_{R}=1.3 \mu \mathrm{W} \cdot \mathrm{m}^{-3}$ and low $\left.H_{R}=0.6 \mu \mathrm{W} \cdot \mathrm{m}^{-3}\right)$. These values are also in agreement with previous compilations from Archean TTG granites (Bea, 2012; Rolandone et al., 2002). Initial thickness of the lithospheric mantle is reduced when applying a lower crustal $H_{R}$ to the model, while evaluating the Moho temperature using the thermal equation (in Section 2.2). This corresponds to lithospheric thickness of $77 \mathrm{~km}$ and $66 \mathrm{~km}$ for the ancient-styled at moderate $H_{R}$ and low $H_{R}$, respectively. Additionally, the initial thickness of the lithosphere for modern-styled reference models is $143 \mathrm{~km}$ and $103 \mathrm{~km}$ at moderate and low $H_{R}$ values. Results and the adjusted initial thickness of the lithospheric mantle are presented in Figs. 9 and 10.

At moderate and low $H_{R}$ values for the ancient-style reference model (Fig. 9A and $B)$, the deformation style remains similar. Cusping of the sedimentary layer allows sediments to reach burial depths of ca. $25 \mathrm{~km}$ depth. Strain is localised within vertically buried sediments. Both moderate and low $H_{R}$ model variants resulted in a flat Moho, witnessing the absence of strain localization in the mantle lithosphere. The maximum crustal strength value and the corresponding depth (i.e., the depth of the brittle-ductile transition) increased from $116 \mathrm{MPa}$ at $8 \mathrm{~km}$ depth (i.e., reference model) to $129 \mathrm{MPa}$ at $9 \mathrm{~km}$ depth and $143 \mathrm{MPa}$ at $10 \mathrm{~km}$ depth for moderate and low $H_{R}$ model variants, respectively. Additionally, the maximum strength for the lithospheric mantle has decreased from $172 \mathrm{MPa}$ (in reference model) to $152 \mathrm{MPa}$ and $136 \mathrm{MPa}$ for the moderate and low $H_{R}$ model variants while maintaining a $30 \mathrm{~km}$ brittle-ductile transition depth, respectively. One major difference is the pressure and temperature of the buried sediments. The maximum temperature of the sediments in moderate and low $H_{R}$ are lower (ca. $325^{\circ} \mathrm{C}$ in Fig. $9 \mathrm{~A}$ and ca. $400^{\circ} \mathrm{C}$ in Fig. 9B) than in the reference model at high $H_{R}$ 
values (ca. $425^{\circ} \mathrm{C}$ in Fig. 3A). Although the sediments undergo cusping in both low and high $H_{R}$ values, the sediments in the low $H_{R}$ model experiences higher pressure conditions (ca. $800 \mathrm{MPa}$ ) than the sediments at high $H_{R}$ value (ca. $500 \mathrm{MPa}$ in Fig. $3 A)$.

Applying a lower $H_{R}$ for the modern-style tectonics model increases the maximum crustal strength and depth of the brittle-ductile transition zone of the crust, from 170 $\mathrm{MPa}$ at $12 \mathrm{~km}$ depth (i.e., reference model) to $184 \mathrm{MPa}$ at $13 \mathrm{~km}$ depth (i.e., moderate $H_{R}$ ) and $212 \mathrm{MPa}$ at $15 \mathrm{~km}$ depth (i.e., low $H_{R}$ ) at initial conditions. Applying a reduced $H_{R}$ has a greater effect on the depth and maximum strength of the lithospheric mantle at initial conditions, from $1093 \mathrm{MPa}$ at $73 \mathrm{~km}$ depth (i.e., reference model) to $782 \mathrm{MPa}$ at $53 \mathrm{~km}$ depth (i.e., moderate $H_{R}$ ) and $663 \mathrm{MPa}$ at $45 \mathrm{~km}$ depth (i.e., low $\left.H_{R}\right)$. However, overall deformation features of the moderate and low $H_{R}$ model variants remained similar (Fig. $10 \mathrm{~A}$ and $\mathrm{B}$ ). The crust continues to exhibit multiple thrusts and major strain localisation occurs within the lithospheric mantle. For reduced $H_{R}$, faults with dip orientations of $30-35^{\circ}$ penetrated deeper within the crust, increasing the amount of asymmetric deformation. The reduction of $H_{R}$ would therefore accentuate modern-style tectonic behaviours.

\subsection{The transition from ancient to modern-style tectonics}

The two deformation styles characterised in this study complement the results already obtained in a recent thermo-mechanical study (Poh et al., 2020). The occurrences of pop-downs and thrusts at the upper parts of the crust are obtained in models at high strain rates $\left(\dot{\varepsilon}_{\mathrm{BG}} \geq 2 \times 10^{-15}\right)$ while sedimentary cusping occurs at low strain rates $\left(\dot{\varepsilon}_{\mathrm{BG}} \leq 1 \times 10^{-15}\right)$. Furthermore, the occurrence of these deformation styles in wider models can be upscaled. According to Poh et al. (2020), their tectonic features are comparable to those found in large accretionary terranes (>400 km) as seen in Precambrian localities (e.g., the 3.4-2.7 Ga Dharwar Craton in India (Chardon et al., 2011) and the 1.69 Ga Terre Adélie Craton in Antarctica (Gapais et al., 2008)).

Our 2D parametric study allows the deciphering of two end-member tectonic models corresponding to the main features of ancient and modern-style tectonics thermo-mechanical parametric study (Fig. 9A). Fig. 9A shows the strength (shear 
stress) of the lithosphere computed using Eqns. 6 and 8 for a wide range of Moho temperature values $\left(T_{\text {Moho }}\right.$ from $525^{\circ} \mathrm{C}$ to $875^{\circ} \mathrm{C}$ ) and background strain rate values ( $\dot{\varepsilon}_{\mathrm{BG}}$ from $5 \times 10^{-17} \mathrm{~s}^{-1}$ to $\left.1 \times 10^{-14} \mathrm{~s}^{-1}\right)$. The initial thickness of the lithosphere corresponds to the lower part of the model where $T<1330^{\circ} \mathrm{C}$ and the geotherm is computed assuming thermal equilibrium.

The maximum crustal strength (i.e., the shear stress of the crust at the brittleductile transition, see Fig. 1A) provides an ideal proxy in explaining the transition between tectonic styles. As such, we consider the occurrence of thrusts in the crust and presence of the deformed lithospheric mantle as the transition from ancient to modern-style tectonics (Fig. 2 and Supplementary Data, Fig. S1). In Fig. 4, this transition begins at $T_{\mathrm{Moho}}=650^{\circ} \mathrm{C}, \dot{\varepsilon}_{\mathrm{BG}}=1 \times 10^{-14} \mathrm{~s}^{-1}, T_{\mathrm{Moho}}=550^{\circ} \mathrm{C}, \dot{\varepsilon}_{\mathrm{BG}}=2 \times 10^{-15} \mathrm{~s}^{-1}$ to $T_{\mathrm{Moho}}=550^{\circ} \mathrm{C}, \dot{\varepsilon}_{\mathrm{BG}}=1 \times 10^{-15} \mathrm{~s}^{-1}$. When compared to the $1 \mathrm{D}$ parametric study, this transition line would correspond to a value of ca. $300 \mathrm{MPa}$ for the crustal strength at the brittle-ductile transition. This result shows that any lithosphere with a maximum crustal strength less than ca. $300 \mathrm{MPa}$ would lead to ancient-style tectonic features. At the opposite, modern-style tectonics will occur for a lithosphere presenting a maximum crustal strength higher than $300 \mathrm{MPa}$ (bottom right corner of Fig. 11A).

Fig. 11B and 11C display similar results using a different crustal rheology and crustal radiogenic heat production, respectively. The shifting of the transition line was monitored from the 1D study when changing the rheology of the crust (Fig. 11B) and crustal radiogenic heat production (Fig. 11C). An increase in crustal strength expands the domain of modern-style tectonics (i.e., transition line moves upwards). Imposing a stronger crustal rheology enabled faulting within the crust in Fig. 8A, indicating that this transition between ancient to modern-style tectonics exists. At the opposite, a decrease in crustal strength increases the domain for ancient-style tectonics. Therefore, this numerical study determines that a transition between the two tectonic styles exists and can be tracked using crustal strength. A decrease in crustal heat production increases crustal strength and thus, expands the domain of modern-style tectonics (Fig. 11C). This indicates that reducing crustal $H_{R}$ accentuate the generation of deformation features akin to modern-style tectonics.

\section{Discussion}

\subsection{Role of crustal radiogenic heat production $\left(H_{R}\right)$}


The accumulation of sediments during shortening to the concentration of minerals (e.g., zircons and monazites) that are enriched in radiogenic heat producing elements (up to $5 \mu \mathrm{W} \cdot \mathrm{m}^{-3}$ in Faccenda et al., 2008). Previous thermo-mechanical numerical studies indicate that the concentration and subsequent burial of such high heat producing rocks is capable of generating localised thermal anomalies within the lithosphere (e.g., Faccenda et al., 2008; Gray and Pysklywec, 2010). These thermal anomalies can lead to the generation of low viscosity regions, that decouple the lower and upper portions of the crust during orogenesis (Sokoutis and Willingshofer, 2011), and trigger additional tectonic processes, such as gravitational instabilities (Gerya et al., 2004) and exhumation (Faccenda et al., 2008).

The $H_{R}$ value of $5.0 \mu \mathrm{W} \cdot \mathrm{m}^{-3}$ used in Faccenda et al. (2008) conforms to the upper limits of $H_{R}$ values for Archean TTGs (Bea, 2012) and is considerably higher than our tested values $\left(H_{R}=0.6,1.3\right.$ and $\left.2.0 \mu \mathrm{W} \cdot \mathrm{m}^{-3}\right)$. If we assign such high values to our reference models, we expect the transition line presented in Fig. 11C to shift downwards, expanding the domain for ancient-style tectonics. When applied, the maximum crustal strength for the high $H_{R}$ variants of the ancient and modern-style reference models was at ca. $170 \mathrm{MPa}$ and $310 \mathrm{MPa}$ after $20 \%$ of horizontal shortening, respectively. Using our maximum crustal strength criterion, we predict that the lithosphere in this modern-style tectonics model will begin to produce some ancient-style deformation features such as the occurrence either more distributed deformation at the upper parts of the crust, reduced strain localisation at the lithospheric mantle, smoother $P-T$ gradients or lower topographic range.

\subsection{Importance of shear heating}

Shear heating has been identified as a natural process to localise and stabilise deformation at crustal scale (Burg and Schmalholz, 2008). It could be also responsible for generating inverted metamorphism sequences as observed at the base of tectonic nappes (Duprat-Oualid et al., 2013). Our models show that shear heating is a key ingredient that trigger the formation of modern-style tectonic features. Switching off shear heating causes the lithospheric mantle to buckle and fold (Fig. 6B). 
However, the role of shear heating for ancient-style tectonics appears to be minor. It suggests that thermo-mechanical conditions of ancient orogens was not favourable to strain localisation by shear heating. We consider the development of prominent shear zones in the mantle as a proxy for subduction initiation; a key ingredient of modern-style tectonics. We have computed the localisation criterion from Kiss et al. (2019) to predict the occurrence of subduction initiation via shear heating (i.e., $T_{S H}$ value from Kiss et al., 2020). Using the parameters for dislocation creep of dry olivine (i.e., the lithospheric mantle in our models), the applied velocity difference, the model length and $200 \mathrm{~km}$ of shortening, the criterion is evaluated to be $T_{S H}-T_{\text {Moho }}>225^{\circ} \mathrm{C}$ . The results are presented in Fig. 11D. When compared to the models from the 2D parametric study (in Fig. 3, Supplementary Data, Fig. S1), the area below the contour of the localisation criteria of $225^{\circ} \mathrm{C}$ covers the same models that are identified to generate modern-style tectonics. This is an excellent agreement between our proposed crustal shear stress criterion (i.e., ca. $300 \mathrm{MPa}$ ) and the prediction of Kiss et al. (2020). Therefore, both criteria can be used to predict the transition between ancient and modern-style tectonics.

\subsection{Implications for Plate tectonics}

Tectonic plates move in part due to the convective process in the mantle. Plates eventually collide, generating deformation belts characterised by either ancient or modernstyle tectonics. In our study, we associate the onset of thrusts and the generation of lithospheric-scale shear zones in the lithospheric mantle as indicators for the occurrence of modern-style tectonics. We observe that crustal faults become prominent when maximum crustal strength exceeds ca. $300 \mathrm{MPa}$ (e.g., Fig. 8A). In contrast, the occurrence of periodic formation of pop-downs and an absence of prominent thrusts in the upper parts of the crust (ancient-like deformation) together with the deformed Moho (modern-like deformation) indicate that a transitional style can exist. This occurs with maximum crustal shear stress of ca. 300 MPa (in Fig. 7B). Previous field studies indeed indicate that both ancient and modern tectonics have occurred coevally as seen in the review of the Finnish Lapland Granulite belt and the Sveconfennian domain (Cagnard et al., 2007, 2011, and references therein). Our models predict that deformation features associated with modern-style tectonics will appear when the crust reaches a maximum shear stress of $300 \mathrm{MPa}$ or a localisation criterion of $225^{\circ} \mathrm{C}$, and fulfil the necessary 
conditions for plate tectonics to occur (e.g., Cawood et al., 2012, 2018).

\subsection{Limitations of model}

In this study, we only used one material to model a homogenous crust (i.e., Westerly granite dislocation creep flow law; Hansen and Carter, 1983). The important point is that crust is modelled by a material with a brittle-ductile transition allowing to test the influence of changing its rheological structure. While testing different temperature gradients, strain rates and flow laws, we consider this modelling choice as representative of the crust. By testing a wide range of the afore-mentioned parameters, we investigated a large range of possible rheological structures for the crust. Using other rheological flow laws (see Section 3.3) leads to the same conclusions concerning the maximum crustal shear stress, allowing to explain the transition between ancient and modern style tectonics. However, results have to be taken with caution as they do not consider a crust composed by more layers. Indeed, rheological layering can have an impact on the structure of orogens (e.g., vergence of wedges; Vogt and Gerya, 2014), and the convergence margins (e.g. due to coupling/decoupling processes; Yamato et al., 2008; Duretz and Gerya, 2013b). In addition, the presence of crustal heterogeneities was not considered. The latter may induce material instabilities such as folding or necking (e.g., Schmalholz and Mancktelow, 2016), formation of second order tectonic nappes, or stress and pressure variations that may affect metamorphism (e.g., Reuber et al., 2016). Heterogeneities can further reduce the magnitude of stress required for subduction initiation and may further increase the asymmetry of orogenic wedges, as already shown in extensional setting (e.g., Petri et al., 2019).

Introducing heterogeneities within the crust due to melt extraction process may also be important. In our model, changes in viscosity, density and latent heat due to partial melting are implemented (see Section 2.1.2). They therefore account for the first order effect due to partial melting even though melt extraction is neglected. The effect of melting in modern-style tectonic models appears minimal but becomes obvious in ancient style tectonics models where this process leads to crustal convection. In these models, the percentage of melt within the lower crust is probably overestimated due to the lack of melt extraction. Consequently, convection in the lower crust is potentially exaggerated. Two phases flow numerical models (e.g., Keller et al., 2013) could be 
used in future studies to address this effect in more detail. However, it is important to note that this method also has limitations as they still struggle to capture end-members (i.e., $100 \%$ solid and to $100 \%$ liquid).

\section{Conclusions}

A combination of $1 \mathrm{D}$ and 2D high-resolution thermo-mechanical numerical models was used to identify and quantify the transition from ancient to modern-style tectonics. Four parameters that control the strength of the lithosphere (i.e., strain rate, Moho temperature, crustal rheology and crustal radiogenic heat production) and the influence of shear heating were investigated. Strain rate remains a key factor that dictates tectonic style. Shear heating was found to be essential in modern-style tectonic models for generating, localising and stabilising strain localisation within the crust and lithospheric mantle. Crustal radiogenic heat production plays a moderate role in the transition from ancient to modern-style tectonics. The transitional tectonic style, which combines features from both ancient and modern-style tectonic models, was also modelled. Our results suggest that the transition between ancient-style and modern-style tectonics correspond to a maximum crustal strength at ca. $300 \mathrm{MPa}$. Moreover, this crustal strength criterion is in excellent agreement with the localisation criterion of ca. $225^{\circ} \mathrm{C}$ found by Kiss et al. (2020), allowing the prediction for shear zones development in lithospheric-scale models. Therefore, these proxies can be used interchangeably to predict the transition between tectonic styles.

\section{Acknowledgements}

This contribution represents the second part of the first author's PhD thesis and was supported financially by Orano Mining. The 2D thermo-mechanical code, MDoodz, can be made available by P. Yamato and T. Duretz upon request. The authors would like to thank R. Chemillac and C. Cutts of Orano for their feedback to the manuscript. We would also like to thank T. Gerya for the editorial handling and two anonymous reviewers for their detailed and constructive reviews. 
621

622

623

624

625

626

627

628

629

630

631

632

633

634

635

636

637

638

639

640

641

642

643

644

645

646

647

648

649

650

651

\section{References}

Anderson, D.L., 2002. The Case for Irreversible Chemical Stratification of the Mantle. Int. Geol. Rev. 44, 97-116. doi:10.2747/0020-6814.44.2.97.

Auzemery, A., Willingshofer, E., Yamato, P., Duretz, T., Sokoutis, D., 2020. Strain localization mechanisms for subduction initiation at passive margins. Glob. Planet. Change 195, 103323. doi:10.1016/j.gloplacha.2020.103323.

Bea, F., 2012. The sources of energy for crustal melting and the geochemistry of heatproducing elements. Lithos 153, 278-291. doi:10.1016/j.lithos.2012.01.017.

Bouhallier, H., Chardon, D., Choukroune, P., 1995. Strain patterns in Archaean domeand-basin structures: The Dharwar craton (Karnataka, South India). Earth Planet. Sci. Lett. 135, 57 - 75. doi:10.1016/0012-821X(95)00144-2.

Brace, W.F., Schulz, C.H., La Mori, P.N., 1969. Isothermal compressibility of kyanite, andalusite, and sillimanite from synthetic aggregates. J. Geophys. Res. 74, 20892098. doi:10.1029/JB074i008p02089.

Brown, M., 2006. Duality of thermal regimes is the distinctive characteristic of plate tectonics since the Neoarchean. Geology 34, 961. doi:10.1130/G22853A.1.

Brown, M., Johnson, T., 2018. Secular change in metamorphism and the onset of global plate tectonics. Am. Mineral. 103, 181-196. doi:10.2138/am-2018-6166.

Brown, M., Johnson, T., Gardiner, N.J., 2020. Plate Tectonics and the Archean Earth. Annu. Rev. Earth Planet. Sci. 48, 291-320. doi:10.1146/ annurev-earth081619-052705.

Burg, J.P., Gerya, T.V., 2005. The role of viscous heating in Barrovian metamorphism of collisional orogens: thermomechanical models and application to the Lepontine Dome in the Central Alps. J. Metamorph. Geol. 23, 75-95. doi:10.1111/j. 1525-1314.2005.00563.x.

Burg, J.P., Schmalholz, S.M., 2008. Viscous heating allows thrusting to overcome crustal-scale buckling: Numerical investigation with application to the Himalayan 
syntaxes. Earth Planet. Sci. Lett. 274, 189 - 203. doi:10.1016/j.epsl.2008.07.022.

653

654

655

656

657

658

659

660

661

662

663

664

665

666

667

668

669

670

671

672

673

674

675

676

677

678

679

680

Burov, E.B., 2011. Rheology and strength of the lithosphere. Mar. Pet. Geol. 28, 1402-1443. doi:10.1016/j.marpetgeo.2011.05.008.

Burov, E.B., Watts, A.B., et al., 2006. The long-term strength of continental lithosphere: "jelly sandwich" or créme brûlée"? GSA today 16, 4.

Cagnard, F., Barbey, P., Gapais, D., 2011. Transition between "Archaean-type" and "modern-type" tectonics: Insights from the Finnish Lapland Granulite Belt. Precambrian Res 187, 127 - 142. doi:10.1016/j.precamres.2011.02.007.

Cagnard, F., Durrieu, N., Gapais, D., Brun, J.P., Ehlers, C., 2006. Crustal thickening and lateral flow during compression of hot lithospheres, with particular reference to Precambrian times. Terra Nova 18, 72-78. doi:10.1111/j.1365-3121.2009.00873. $\mathrm{X}$.

Cagnard, F., Gapais, D., Barbey, P., 2007. Collision tectonics involving juvenile crust: The example of the southern Finnish Svecofennides. Precambrian Res 154, 125 141. doi:10.1016/j.precamres.2006.12.011.

Capitanio, F.A., Nebel, O., Cawood, P.A., Weinberg, R.F., Chowdhury, P., 2019. Reconciling thermal regimes and tectonics of the early Earth. Geology 47, 923927. doi:10.1130/G46239.1.

Cawood, P.A., Hawkesworth, C.J., Dhuime, B., 2012. The continental record and the generation of continental crust. Geol. Soc. Am. Bull. 125, 14-32. doi:10.1130/ b30722.1.

Cawood, P.A., Hawkesworth, C.J., Pisarevsky, S.A., Dhuime, B., Capitanio, F.A., Nebel, O., 2018. Geological archive of the onset of plate tectonics. Philos. Trans. R. Soc. A: Math. Phys. Eng. Sci. 376, 20170405. doi:10.1098/rsta.2017.0405.

Chardon, D., Gapais, D., Cagnard, F., 2009. Flow of ultra-hotorogens: A view from the Precambrian, clues for the Phanerozoic. Tectonophysics 477, 105 - 118. doi:10. 1016/j.tecto.2009.03.008.

Chardon, D., Jayananda, M., Peucat, J.J., 2011. Lateral constrictional flow of hot orogenic crust: Insights from the Neoarchean of south India, geological and 
geophysical implications for orogenic plateaux. Geochem. Geophys. Geosyst. 12, n/a-n/a. doi:10.1029/2010gc003398.

683

Chopra, P.N., Paterson, M.S., 1984. The role of water in the deformation of dunite. Journal of Geophysical Research: Solid Earth 89, 7861-7876. doi:10.1029/ jb089ib09p07861.

Choukroune, P., Bouhallier, H., Arndt, N., 1995. Soft lithosphere during periods of Archaean crustal growth or crustal reworking. Geol. Soc. London Spec. Publ. 95, 67-86. doi:10.1144/GSL.SP.1995.095.01.05.

Condie, K.C., Aster, R.C., van Hunen, J., 2016. A great thermal divergence in the mantle beginning $2.5 \mathrm{Ga}$ : Geochemical constraints from greenstone basalts and komatiites. Geosci. Front. 7, 543-553. doi:http://dx.doi.org/10.1016/j.gsf. 2016.01.006.

Condie, K.C., Benn, K., 2006. Archean geodynamics: Similar to or different from modern geodynamics? Geophysical Monograph-American Geophysical Union 164, 47-59. doi:10.1029/164GM05.

Cruden, A.R., Nasseri, M.H.B., Pysklywec, R., 2006. Surface topography and internal strain variation in wide hot orogens from three-dimensional analogue and twodimensional numerical vice models. Geol. Soc. London Spec. Publ. 253, 79-104. doi:10.1144/gsl.sp.2006.253.01.04.

Duclaux, G., Rey, P., Guillot, S., Ménot, R.P., 2007. Orogen-parallel flow during continental convergence: Numerical experiments and Archean field examples. Geology 35, 715. doi:10.1130/g23540a.1.

Duprat-Oualid, S., Yamato, P., Pitra, P., 2013. Major role of shear heating in intracontinental inverted metamorphism: Inference from a thermo-kinematic parametric study. Tectonophysics 608, 812 - 831. doi:10.1016/j.tecto.2013.07.037.

Duretz, T., Gerya, T.V., 2013a. Slab detachment during continental collision: Influence of crustal rheology and interaction with lithospheric delamination. Tectonophysics 602, 124 - 140. doi:10.1016/j.tecto.2012.12.024.

Duretz, T., Gerya, T.V., 2013b. Slab detachment during continental collision: Influence 
of crustal rheology and interaction with lithospheric delamination. Tectonophysics 602, 124-140. doi:10.1016/j.tecto.2012.12.024.

713

714

Duretz, T., Petri, B., Mohn, G., Schmalholz, S.M., Schenker, F.L., Mü ntener, O., 2016. The importance of structural softening for the evolution and architecture of passive margins. Sci. Rep. 6. doi:10.1038/srep38704.

Duretz, T., Schmalholz, S.M., Podladchikov, Y.Y., Yuen, D.A., 2014. Physics-controlled thickness of shear zones caused by viscous heating: Implications for crustal shear localization. Geophys. Res. Lett. 41, 4904-4911. doi:10.1002/2014GL060438.

Faccenda, M., Gerya, T.V., Chakraborty, S., 2008. Styles of post-subduction collisional orogeny: Influence of convergence velocity, crustal rheology and radiogenic heat production. Lithos 103, 257 - 287. doi:10.1016/j.lithos.2007.09.009.

Gapais, D., 2018. Tectonics-mineralisation relationships within weak continental lithospheres: a new structural framework for Precambrian cratons Relations tectonique- minéralisation dans les lithosphères continentales chaudes, applications aux cratons précambriens. Bulletin de la Société Géologique de France 189, 14. doi:10.1051/bsgf/2018014.

Gapais, D., Cagnard, F., Gueydan, F., Barbey, P., Ballèvre, M., 2009. Mountain building and exhumation processes through time: inferences from nature and models. Terra Nova 21, 188-194. doi:10.1111/j.1365-3121.2009.00873.x.

Gapais, D., Jaguin, J., Cagnard, F., Boulvais, P., 2014. Pop-down tectonics, fluid channelling and ore deposits within ancient hot orogens. Tectonophysics $618,102-$ 106. doi:10.1016/j.tecto.2014.01.027.

Gapais, D., Pelletier, A., Ménot, R.P., Peucat, J.J., 2008. Paleoproterozoic tectonics in the Terre Adélie Craton (East Antarctica). Precambrian Res 162, 531 - 539. doi:10.1016/j.precamres.2007.10.011.

Gapais, D., Potrel, A., Machado, N., Hallot, E., 2005. Kinematics of long-lasting Paleoproterozoic transpression within the Thompson Nickel Belt, Manitoba, Canada. Tectonics 24, TC3002. doi:10.1029/2004TC001700.

Gerya, T., 2019a. Geodynamics of the early Earth: Quest for the missing paradigm. Geology 47, 1006-1007. doi:10.1130/focus102019.1. 
Gerya, T., 2019b. Introduction to numerical geodynamic modelling. 2nd ed., Cambridge University Press. doi:10.1017/9781316534243.

744

745

746

747

748

749

750

751

752

753

754

755

756

757

758

759

760

761

762

763

764

765

766

767

768

769

Gerya, T.V., Perchuk, L.L., Maresch, W.V., Willner, A.P., 2004. Inherent gravitational instability of hot continental crust: Implications for doming and diapirism in granulitefacies terrains, in: Gneiss Domes in Orogeny. Geological Society of America. doi:10. 1130/0-8137-2380-9.97.

Gerya, T.V., Yuen, D.A., 2003. Rayleigh-Taylor instabilities from hydration and melting propel 'cold plumes' at subduction zones. Earth Planet. Sci. Lett. 212, 47-62. doi:10.1016/S0012-821X(03)00265-6.

Goes, S., Hasterok, D., Schutt, D.L., Klöcking, M., 2020. Continental lithospheric temperatures: A review. Phys. Earth Planet. In. 306, 106509. doi:10.1016/j.pepi. 2020.106509.

Gray, R., Pysklywec, R.N., 2010. Geodynamic models of Archean continental collision and the formation of mantle lithosphere keels. Geophys. Res. Lett. 37. doi:10.1029/2010GL043965.

Hansen, F.D., Carter, N.L., 1983. Semibrittle creep of dry and wet Westerly granite at 1000 MPa, in: The 24th US Symposium on Rock Mechanics (USRMS), American Rock Mechanics Association, College Station, Texas.

Hawkesworth, C.J., Brown, M., 2018. Earth dynamics and the development of plate tectonics. Philos. Trans. R. Soc. A: Math. Phys. Eng. Sci. 376, 20180228. doi:10. 1098/rsta.2018.0228.

Hirth, G., Kohlstedt, D., 2004. Rheology of the Upper Mantle and the Mantle Wedge: A View from the Experimentalists. American Geophysical Union (AGU). chapter Chapter 6. pp. 83-105. doi:10.1029/138GM06.

Holder, R.M., Viete, D.R., Brown, M., Johnson, T.E., 2019. Metamorphism and the evolution of plate tectonics. Nature 572, 378-381. doi:10.1038/s41586-019-14622.

Jackson, J.A., 2002. Strength of the continental lithosphere: time to abandon the jelly 
sandwich? GSA today $12,4-10$.

771

772

773

774

775

776

777

778

779

780

781

782

783

784

785

786

787

788

789

790

791

792

793

794

795

796

797

798

Jaupart, C., Mareschal, J.C., larotsky, L., 2016. Radiogenic heat production in the continental crust. Lithos 262, 398-427. doi:10.1016/j.lithos.2016.07.017.

Johnson, T.E., Kirkland, C.L., Gardiner, N.J., Brown, M., Smithies, R.H., Santosh, M., 2019. Secular change in TTG compositions: Implications for the evolution of Archaean geodynamics. Earth Planet. Sci. Lett. 505, 65-75. doi:10.1016/j.epsl. 2018.10.022.

Keller, T., May, D.A., Kaus, B.J.P., 2013. Numerical modelling of magma dynamics coupled to tectonic deformation of lithosphere and crust. Geophys. J. Int. 195, 14061442. doi:10.1093/gji/ggt306.

Kiss, D., Duretz, T., Schmalholz, S.M., 2020. Tectonic inheritance controls nappe detachment, transport and stacking in the Helvetic nappe system, Switzerland: insights from thermomechanical simulations. Solid Earth 11, 287-305. doi:10.5194/ se-11-287-2020.

Kiss, D., Podladchikov, Y., Duretz, T., Schmalholz, S.M., 2019. Spontaneous generation of ductile shear zones by thermal softening: Localization criterion, $1 D$ to 3D modelling and application to the lithosphere. Earth Planet. Sci. Lett. 519, 284-296. doi:10.1016/j.epsl.2019.05.026.

Lenardic, A., 2018. The diversity of tectonic modes and thoughts about transitions between them. Philos. Trans. R. Soc. A: Math. Phys. Eng. Sci. 376, 20170416. doi:10.1098/rsta.2017.0416.

Liao, J., Gerya, T., 2017. Partitioning of crustal shortening during continental collision: 2-D thermomechanical modeling. Journal of Geophysical Research: Solid Earth 122, 592-606. doi:10.1002/2016JB013398.

Mareschal, J.C., Jaupart, C., 2013. Radiogenic heat production, thermal regime and evolution of continental crust. Tectonophysics 609, 524-534. doi:10.1016/j.tecto. 2012.12.001.

Martin, H., Moyen, J.F., 2002. Secular changes in tonalite-trondhjemite-granodiorite composition as markers of the progressive cooling of Earth. Geology 30, 319-322. 
800

801

802

803

804

805

806

807

808

809

810

811

812

813

814

815

816

817

818

819

820

821

822

Miyashiro, A., 1961. Evolution of Metamorphic Belts. J. Petrol. 2, 277-311. doi:10. 1093/petrology/2.3.277.

Nebel, O., Capitanio, F.A., Moyen, J.F., Weinberg, R.F., Clos, F., Nebel-Jacobsen, Y.J., Cawood, P.A., 2018. When crust comes of age: on the chemical evolution of Archaean, felsic continental crust by crustal drip tectonics. Philos. Trans. R. Soc. A: Math. Phys. Eng. Sci. 376, 20180103. doi:10.1098/rsta.2018.0103.

Palin, R.M., Santosh, M., 2020. Plate tectonics: What, where, why, and when? Gondwana Res. doi:10.1016/j.gr.2020.11.001.

Palin, R.M., Santosh, M., Cao, W., Li, S.S., Hernández-Uribe, D., Parsons, A., 2020. Secular change and the onset of plate tectonics on Earth. Earth Sci. Rev. 207, 103172. URL: https://www.sciencedirect.com/science/article/pii/ S001282522030218X, doi:10.1016/j.earscirev.2020.103172.

Perchuk, A.L., Safonov, O.G., Smit, C.A., van Reenen, D.D., Zakharov, V.S., Gerya, T.V., 2018. Precambrian ultra-hot orogenic factory: Making and reworking of continental crust. Tectonophysics 746, 572-586. doi:10.1016/j.tecto.2016.11.041.

Petri, B., Duretz, T., Mohn, G., Schmalholz, S.M., Karner, G.D., Mü ntener, O., 2019. Thinning mechanisms of heterogeneous continental lithosphere. Earth Planet. Sci. Lett. 512, 147-162. doi:10.1016/j.epsl.2019.02.007.

Poh, J., Yamato, P., Duretz, T., Gapais, D., Ledru, P., 2020. Precambrian deformation zones in compressional tectonic regimes: a numerical perspective. Tectonophysics 777, 1-17. doi:10.1016/j.tecto.2020.228350.

Poli, S., Schmidt, M.W., 2002. Petrology of Subducted Slabs. Annu. Rev. Earth Planet. Sci. 30, 207-235. doi:10.1146/annurev.earth.30.091201.140550.

Ranalli, G., 1995. Rheology of the Earth. Second ed., Springer Science \& Business Media.

Ranalli, G., 1997. Rheology of the lithosphere in space and time. Geol. Soc. London Spec. Publ. 121, 19-37. doi:10.1144/gsl.sp.1997.121.01.02. 
Reuber, G., Kaus, B.J.P., Schmalholz, S.M., White, R.W., 2016. Nonlithostatic pressure during subduction and collision and the formation of (ultra)high-pressure rocks. Geology 44, 343-346. doi:10.1130/G37595.1.

Rey, P.F., Coltice, N., 2008. Neoarchean lithospheric strengthening and the coupling of Earth's geochemical reservoirs. Geology 36, 635-638. doi:10.1130/G25031A.1.

Rey, P.F., Coltice, N., Flament, N., 2014. Spreading continents kick-started plate tectonics. Nature 513, 405-408. doi:10.1038/nature13728.

Rey, P.F., Houseman, G., 2006. Lithospheric scale gravitational flow: the impact of body forces on orogenic processes from Archaean to Phanerozoic. Geol. Soc. London Spec. Publ. 253, 153-167. doi:10.1144/gsl.sp.2006.253.01.08.

Rogers, J.J.W., Santosh, M., 2004. Continents and Supercontinents. Oxford University Press, New York. doi:10.1093/oso/9780195165890.001.0001.

Rolandone, F., Jaupart, C., Mareschal, J.C., Gariépy, C., Bienfait, G., Carbonne, C., Lapointe, R., 2002. Surface heat flow, crustal temperatures and mantle heat flow in the Proterozoic Trans-Hudson Orogen, Canadian Shield. Journal of Geophysical Research: Solid Earth 107, ETG 7-1-ETG 7-19. doi:10.1029/2001JB000698.

Schmalholz, S.M., Mancktelow, N.S., 2016. Folding and necking across the scales: a review of theoretical and experimental results and their applications. Solid Earth 7 , 1417-1465. doi:10.5194/se-7-1417-2016.

Schmid, S.M., Kissling, E., Diehl, T., van Hinsbergen, D.J.J., Molli, G., 2017. Ivrea mantle wedge, arc of the Western Alps, and kinematic evolution of the AlpsApennines orogenic system. Swiss J Geosci 110, 581-612. doi:10.1007/ s00015016-0237-0.

Schmidt, M.W., Poli, S., 1998. Experimentally based water budgets for dehydrating slabs and consequences for arc magma generation. Earth Planet. Sci. Lett. 163, 361 - 379. doi:10.1016/s0012-821x(98)00142-3.

de Sigoyer, J., Guillot, S., Dick, P., 2004. Exhumation of the ultrahigh-pressure Tso Morari unit in eastern Ladakh (NW Himalaya): A case study. Tectonics 23, 1-18. doi:10.1029/2002tc001492. 
858

859

860

861

862

863

864

865

866

867

868

869

870

871

872

873

874

875

876

877

878

879

880

881

882

883

884

885

886

887

Sizova, E., Gerya, T., Brown, M., Perchuk, L.L., 2010. Subduction styles in the Precambrian: Insight from numerical experiments. Lithos 116, 209-229. doi:10.1016/ j.lithos.2009.05.028.

Sizova, E., Gerya, T., Stüwe, K., Brown, M., 2015. Generation of felsic crust in the Archean: A geodynamic modeling perspective. Precambrian Res 271, 198-224. doi:10.1016/j.precamres.2015.10.005.

Sokoutis, D., Willingshofer, E., 2011. Decoupling during continental collision and intraplate deformation. Earth Planet. Sci. Lett. 305, 435-444. doi:10.1016/j.epsl.2011. 03.028.

Tang, M., Chen, K., Rudnick, R.L., 2016. Archean upper crust transition from mafic to felsic marks the onset of plate tectonics. Science 351, 372-375. doi:10.1126/ science.aad5513.

Thielmann, M., Kaus, B.J.P., 2012. Shear heating induced lithospheric-scale localization: Does it result in subduction? Earth Planet. Sci. Lett. 359-360, 1 - 13. doi:10.1016/j.epsl.2012.10.002.

Turcotte, D., Schubert, G., 2014. Geodynamics. Cambridge University Press. doi:10. 1017/CBO9780511843877.

Vogt, K., Gerya, T.V., 2014. From oceanic plateaus to allochthonous terranes: Numerical modelling. Gondwana Res. 25, 494-508. doi:10.1016/j.gr.2012.11.002.

Yamato, P., Burov, E., Agard, P., Le Pourhiet, L., Jolivet, L., 2008. HP-UHP exhumation during slow continental subduction: Self-consistent thermodynamically and thermomechanically coupled model with application to the Western Alps. Earth Planet. Sci. Lett. 271, 63 - 74. doi:https://doi.org/10.1016/j.epsl.2008.03.049.

Yamato, P., Duretz, T., Angiboust, S., 2019. Brittle/Ductile Deformation of Eclogites: Insights From Numerical Models. Geochem. Geophys. Geosyst. 20, 3116-3133. doi:10.1029/2019GC008249.

Yamato, P., Mouthereau, F., Burov, E., 2009. Taiwan mountain building: Insights from 2-D thermomechanical modelling of a rheologically stratified lithosphere. Geophys. J. Int. 176, 307-326. doi:10.1111/j.1365-246X.2008.03977.x. 


\section{Tables and Figures}

Table 1: Rheological and thermal values used in our study. References for rheological flow laws and partial melting are: $a=$ Ranalli (1997); $b=$ Ranalli (1995); c = Hansen and Carter (1983); d = Chopra and Paterson (1984); e = Schmidt and Poli (1998); $\mathrm{f}=$ Poli and Schmidt (2002); g = Turcotte and Schubert (2014); $\mathrm{h}$

= Gerya (2019b). References for thermal properties are: $\mathrm{i}=$ Turcotte and Schubert (2014); j = Brace et al. (1969); $\mathrm{k}=$ Bea (2012). 
Figure 1: $[A]$ Thermal profiles (in red) and yield strength envelopes (in black) for the two reference models in compression (values used in Table 1). Coloured squares indicate position of reference model in parametric study in Fig. 3 and in subsequent figures. $[B]$ The 2D thermo-mechanical model configuration and boundary conditions (see text for details). $V$ represents the model's convergence and output velocities which was computed from $\dot{\varepsilon}_{B G}$ to satisfy mass balance.

Figure 2: Distribution of ancient-style and modern-style deformation modes obtained from our 2D parametric study (see Supplementary Data, Fig. S1). The vertical and horizontal axes correspond to $T_{\text {Moho }}$ and $\dot{\varepsilon}_{B G}$, respectively. Classifying ancient or modern-style tectonics is determined by the characterisation of deformation of the upper parts of the crust and lithospheric mantle by three main factors (see end of Section 1.2). The selected reference models (from Fig. 1B) to be referred to the rest of the investigation corresponds to the coloured boxes (red: Ancient-style tectonics; blue, modernstyle tectonics). The transition from ancient to modern-style tectonics remains qualitative until the $1 \mathrm{D}$ parametric studies in Fig. 11A and D.

Figure 3: Composition (top), viscosity (middle) and accumulated strain (bottom) fields for reference models after ca. $320 \mathrm{~km}$ of horizontal shortening. [A] Reference model displaying cusping of the sedimentary layer, low topography and by a Moho remaining flat, $[B]$ Reference model for modernstyle tectonics display the formation of high viscosity wedges (i.e., Pop-downs), formation of thrusts and shear zones in the upper parts of the crust and lithospheric mantle, and high topography. Isobars are represented by the white and blue solid lines in the composition (top) and viscosity (centre) plots, respectively. Isotherms are represented by the black and white solid lines in the composition (top) and viscosity (middle) plots, respectively. The upper and lower dashed lines shown in the accumulated strain field (down) highlights the extent of the sedimentary layer and Moho, respectively.

Figure 4: Topography evolution up to ca. $320 \mathrm{~km}$ of horizontal shortening in the two reference models, [A] Ancient-style tectonics and [B] Modern-style tectonics.

Figure 5: Role of shear heating on deformation in ancient-style tectonics reference model after ca. $320 \mathrm{~km}$ of horizontal shortening. The deformation features for both models exhibit similar distributed buckling and cusping of the sedimentary layer. Legends for isotherms, isobars and dashed lines are as for Fig. 3. 
Figure 6: Role of shear heating on deformation in modern-style tectonics reference model after ca. 160 $\mathrm{km}$ of horizontal shortening. Legends for isotherms, isobars and dashed lines are as for Fig. 3.

Figure 7: Role of crustal rheology using weak crust on the $[A]$ ancient-style and $[B]$ modern-style reference models after ca. $320 \mathrm{~km}$ of shortening. In [A], deformation of the crust remains distributed with well-established convecting partially melted at the lower parts of the crust. In $[B]$, deformation becomes symmetrical with the burial of pop-downs and a downward deflection of the Moho. Crustal thickness at the centre reached to approximately $100 \mathrm{~km}$. Legends for isotherms, isobars and dashed lines are as for Fig. 3.

Figure 8: Role of crustal rheology using strong crust on the $[A]$ ancient-style and $[B]$ modern-style reference models after ca. $320 \mathrm{~km}$ of shortening. In [A], the sedimentary cusps begin to generate a series of inverse faults while maintaining a flat Moho. In $[B]$, dominant shear localisation is accompanied with the buckling of the lithospheric mantle and thrusts at the crust. Legends for isotherms, isobars and dashed lines are as for Fig. 3.

Figure 9: Role of $[\mathrm{A}]$ moderate and $[\mathrm{B}]$ low $H_{R}$ crustal radiogenic heat production values on the ancientstyle reference model after ca. $320 \mathrm{~km}$ of horizontal shortening. In both models, deformation patterns are characterised with the cusping of sedimentary layer and maintaining a flat Moho. In $[\mathrm{A}]$, deformation patterns remain comparable to the reference model in Fig. 3A. In $[B]$, the number of folds at the upper parts of the crust decreased indicating an increase in lateral distance when compared to $[A]$. Additionally, the number of high strain accumulation at the Moho in [B] has increased from 1 to 3 . Legends for isotherms, isobars and dashed lines are as for Fig. 3.

Figure 10: Role of moderate and low $H_{R}$ crustal radiogenic heat production values on the modernstyle reference model based on snapshots of the composition (top), viscosity (centre) and accumulated strain (bottom) fields after ca. $320 \mathrm{~km}$ and $280 \mathrm{~km}$ of horizontal shortening in $[A]$ and $[B]$, respectively. Thrusts of the upper parts of the crust and shearing of the lithospheric mantle dominate both models with reduced $H_{R}$. In $[\mathrm{A}]$, two prominent shear zones are located at lithospheric mantle. The lithospheric mantle is observed to bend at the centre while maintaining a lithospheric-scaled shear zone in $[B]$. Legends for isotherms, isobars and dashed lines are as for Fig. 3. 
Figure 11: Results from the 1D parametric study displaying $[A]$ the maximum strength of the crust, $[B]$ the influence of the crustal rheology and [C] the influence of the radiogenic heat production $\left(H_{R}\right)$. Red and blue squares correspond to the ancient and modern-style tectonics reference models, respectively (see Fig. 3). The dark circles and diamonds represent identified ancient and modern-style tectonics in the parametric study (seen in Fig. 4 and Supplementary Data, Fig. S1). Solid black line represents the suggested contour maximum crustal strength of ca. $300 \mathrm{MPa}$ as a first order transition from ancient to modern-style tectonics. This contour shifts vertically based on the variations of crustal strength and $H_{R}$ [D] Parametric study varying $T_{\text {Moho }}$ and $\dot{\varepsilon}_{B G}$ considering the dislocation creep of dry olivine (i.e., lithospheric mantle), applied velocity $(v)$, model length $\left(L_{x}\right)$ and at $50 \%$ horizontal shortening to evaluate the localisation criterion for subduction initiation in Kiss et al. (2019). This criterion is evaluated based on the temperature difference caused by shear heating $\left(T_{\mathrm{SH}}\right)$ and Moho temperature $\left(T_{\text {Moho }}\right)$. The parametric study indicates the temperature difference required for modern-style tectonics begins atca. $225^{\circ} \mathrm{C}$. When compared to the maximum crustal strength of ca. $300 \mathrm{MPa}$, this criterion provides an excellent fit. 


\section{Supplementary Data}

Supplementary Data, Figure S1: 2D parametric study of the viscosity and accumulated strain fields after ca. $320 \mathrm{~km}$ of shortening. Primary parameters varied are Moho temperature $\left(T_{\text {Moho }}\right)$ and background strain rate $\left(\dot{\varepsilon}_{B G}\right)$ that defines the geotherm and convergence velocity, respectively (explained in Fig. 1). The rheology and radiogenic heat production applied to the crust of the model is Dry Westerly Granite (Hansen and Carter, 1983) and $2.0 \mu \mathrm{W} . \mathrm{m}^{-3}$, respectively. Dashed lines represent the outline of the sedimentary layer and the Moho. The 500 and $800 \mathrm{MPa}$ isobars are represented by blue solid lines in the viscosity (top) plots. Isotherms are represented by solid white lines in increments of $100^{\circ} \mathrm{C}$ (from $100^{\circ} \mathrm{C}$ to $700^{\circ} \mathrm{C}$ ) in the model's viscosity and accumulated strain fields. Arrows shown in the models' viscosity fields are not drawn according to scale. The deformation modes are controlled by the intensity of $\dot{\varepsilon}_{B G}$ which is referred in Fig. 2 . Models identified as more ancient-style (in red frames) have distributed deformation and minimal shear zone generation at the upper parts of the crust and lithospheric mantle, low topography ranges and homogeneous $P-T$ distributions. In contrast, models identified as more modern-style (in blue frame) have dominant thrusts and shear zones at the crust and lithospheric mantle, high topography ranges and asymmetric distribution of $P$ - $T$ lines. 


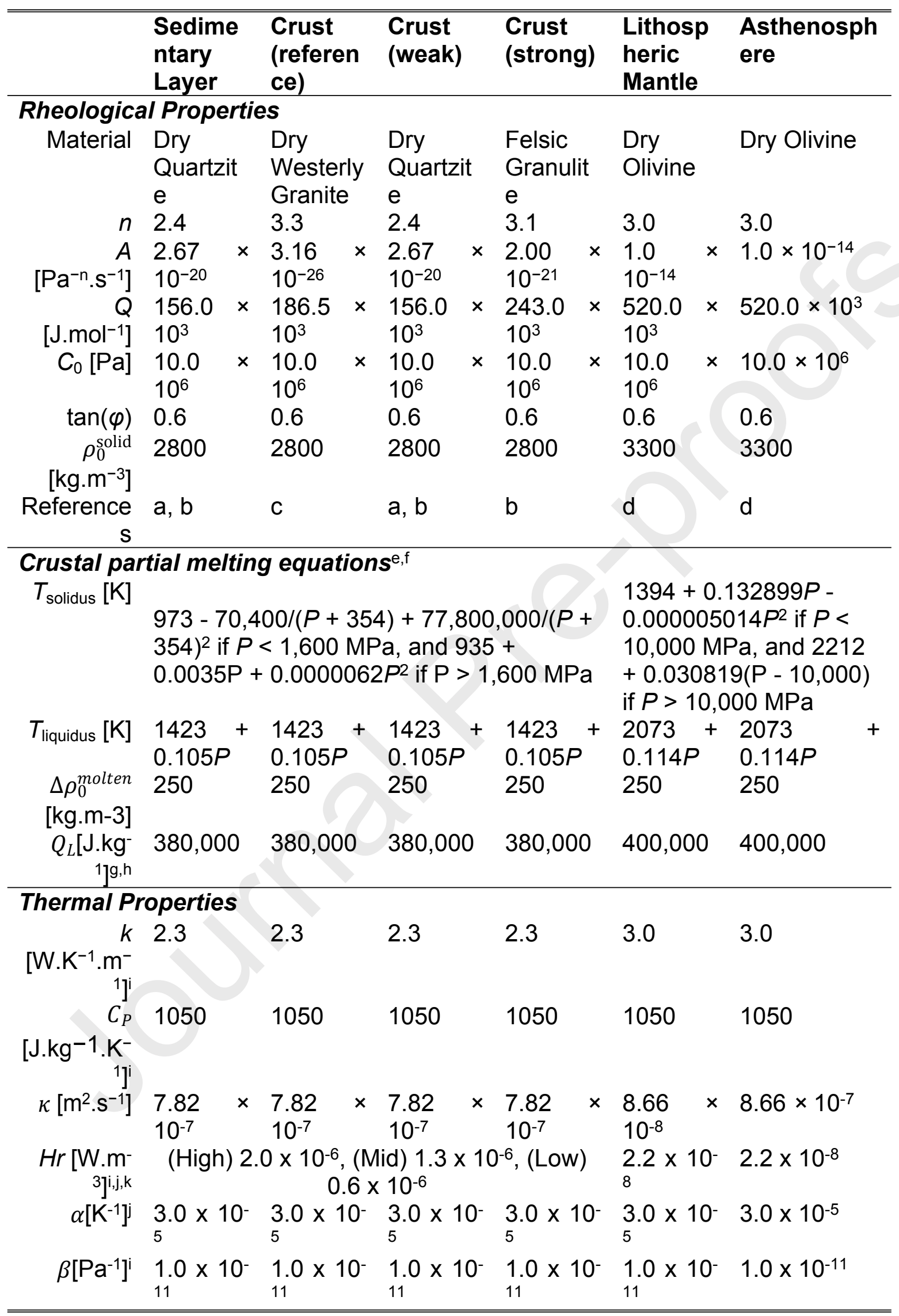




\section{Research Highlights}

- The magnitude of the crustal shear stress dictates the tectonic style.

- Modern style tectonics occurs for a maximum crustal shear stress > $300 \mathrm{MPa}$.

- Shear heating is a key factor for strain localisation in modern style tectonics. 


\section{CRediT author statement for Gondwana Research Submission}

Jonathan Poh: Conceptualisation, Methodology, Investigation, Writing - Original Draft, Writing -Review \& Editing.

Philippe Yamato: Supervision, Software, Resources, Writing - Review \& Editing, Conceptualisation, Validation, Data Curation, Visualisation

Thibault Duretz: Software, Validation, Methodology, Writing - Review \& Editing, Investigation, Data Curation, Visualisation

Denis Gapais: Conceptualisation, Validation.

Patrick Ledru: Validation, Funding acquisition, Writing - Review \& Editing 
[A] REFERENCE MODELS YIELD STRENGTH ENVELOPES
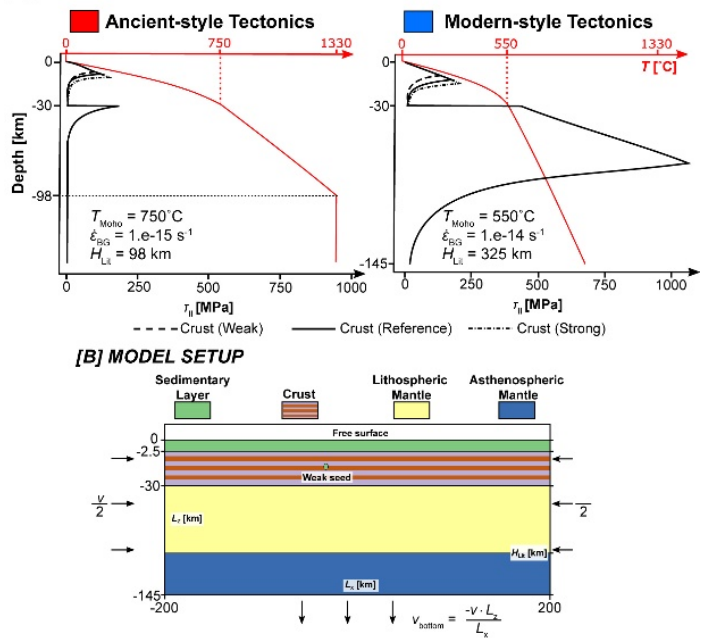


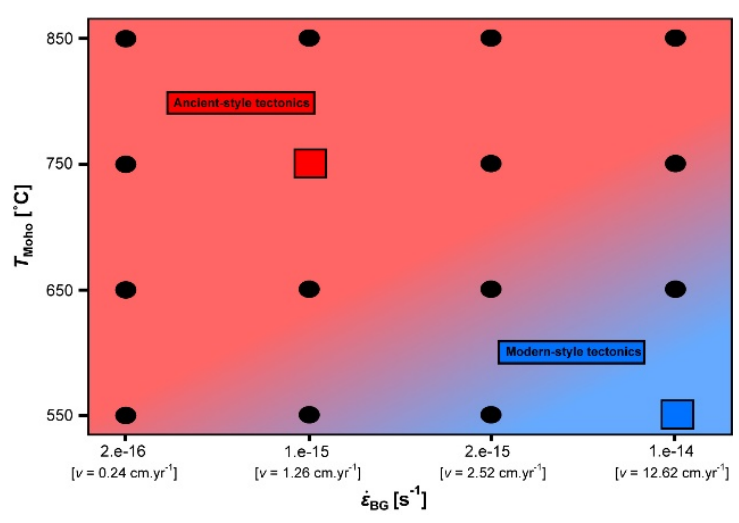




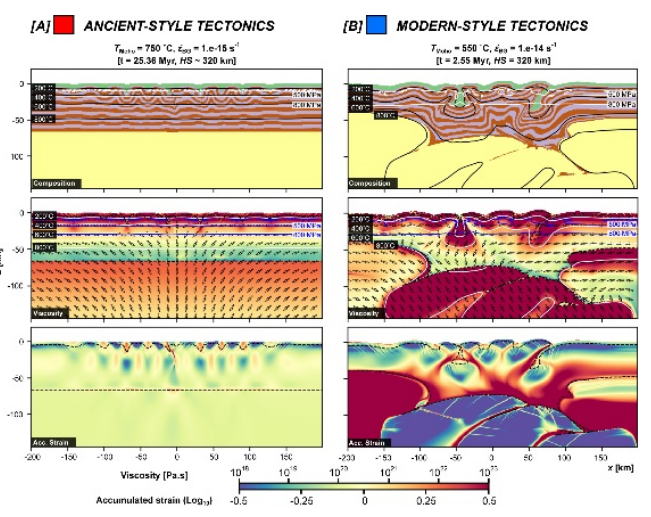


REFERENCE MODELS' TOPOGRAPHY EVOLUTION
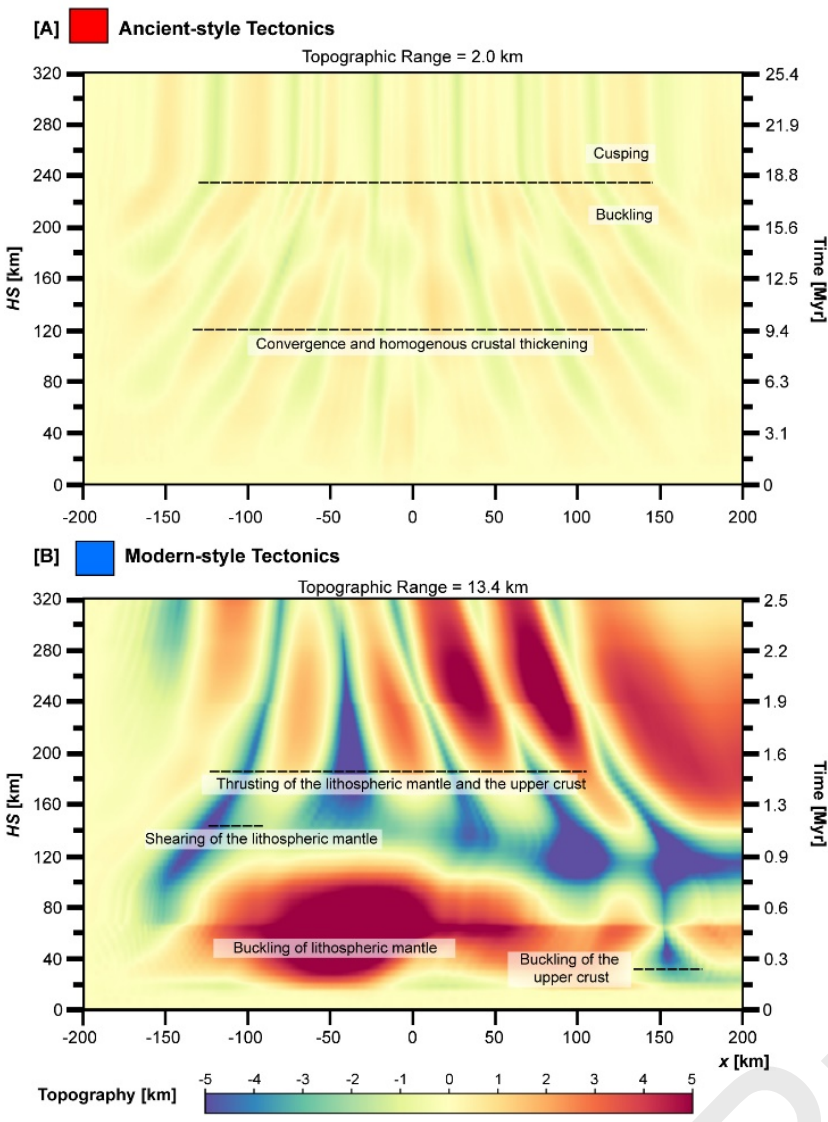
ROLE OF SHEAR HEATING IN ANCIENT-STYLE TECTONICS

-

WTTHOUT SHEAR HEATING

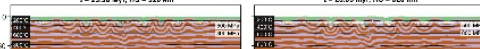

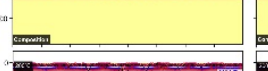

$+\ldots$

䵬

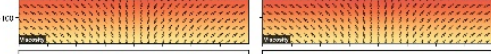

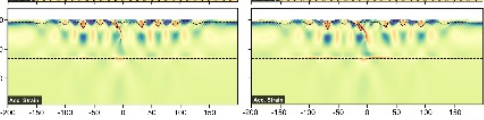

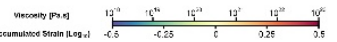




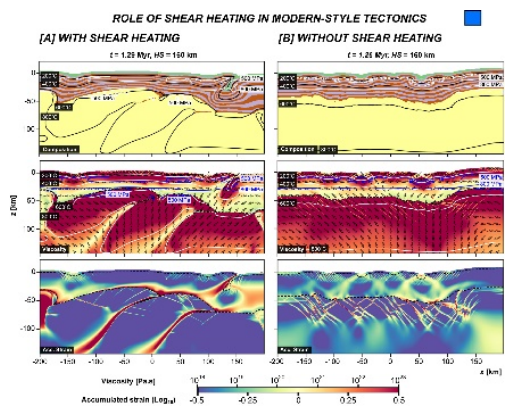


ROLE OF CRUSTAL RHEOLOGY (WEAK CRUST - DRY QUARTZITE)

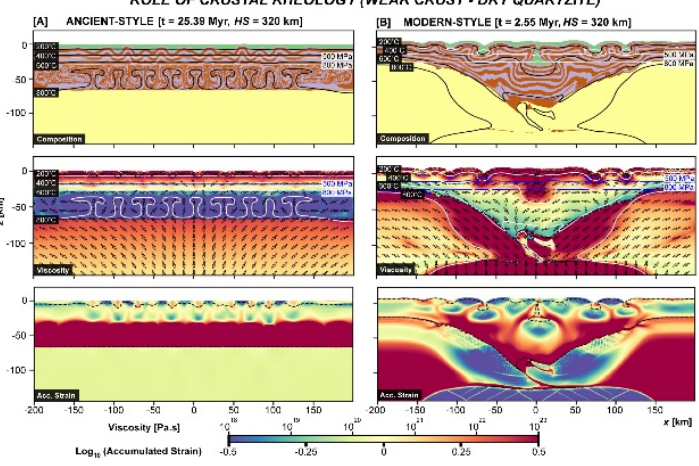


ROLE OF CRUSTAL RHEOLOGY (STRONG CRUST - FELSIC GRANULITE)
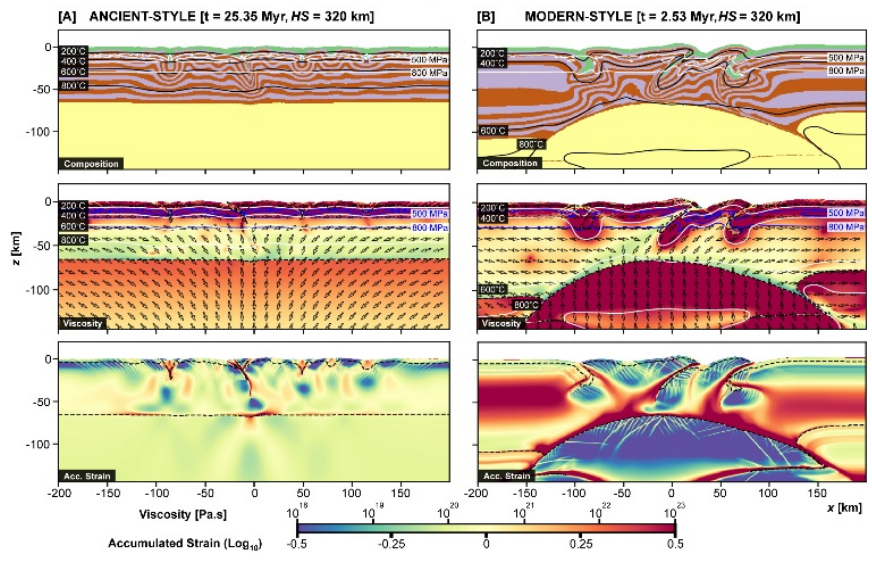
[A] ROLE OF CRUSTAL RADIOGENIC HEAT PRODUCTION (HA) FOR ANCIENT-STYL

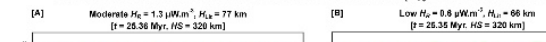
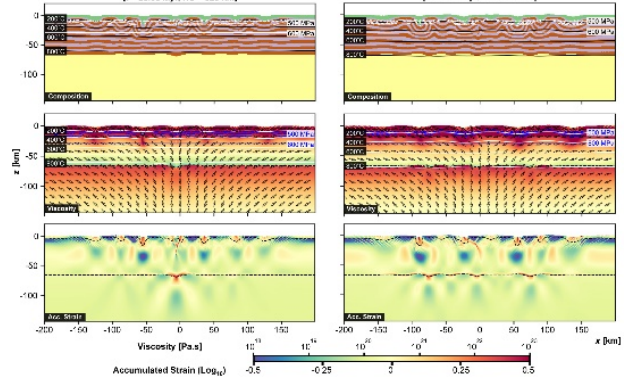


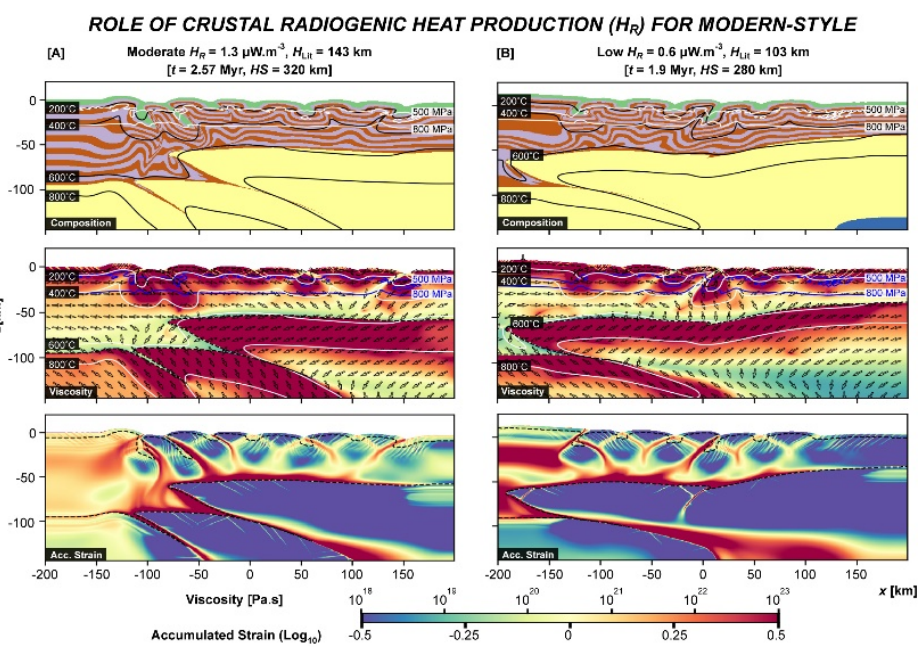



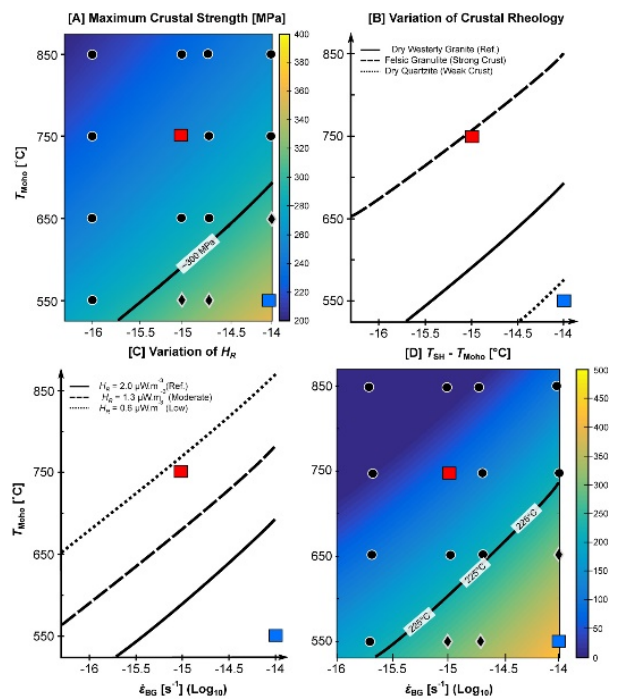
Proxies that predict tectonic style:
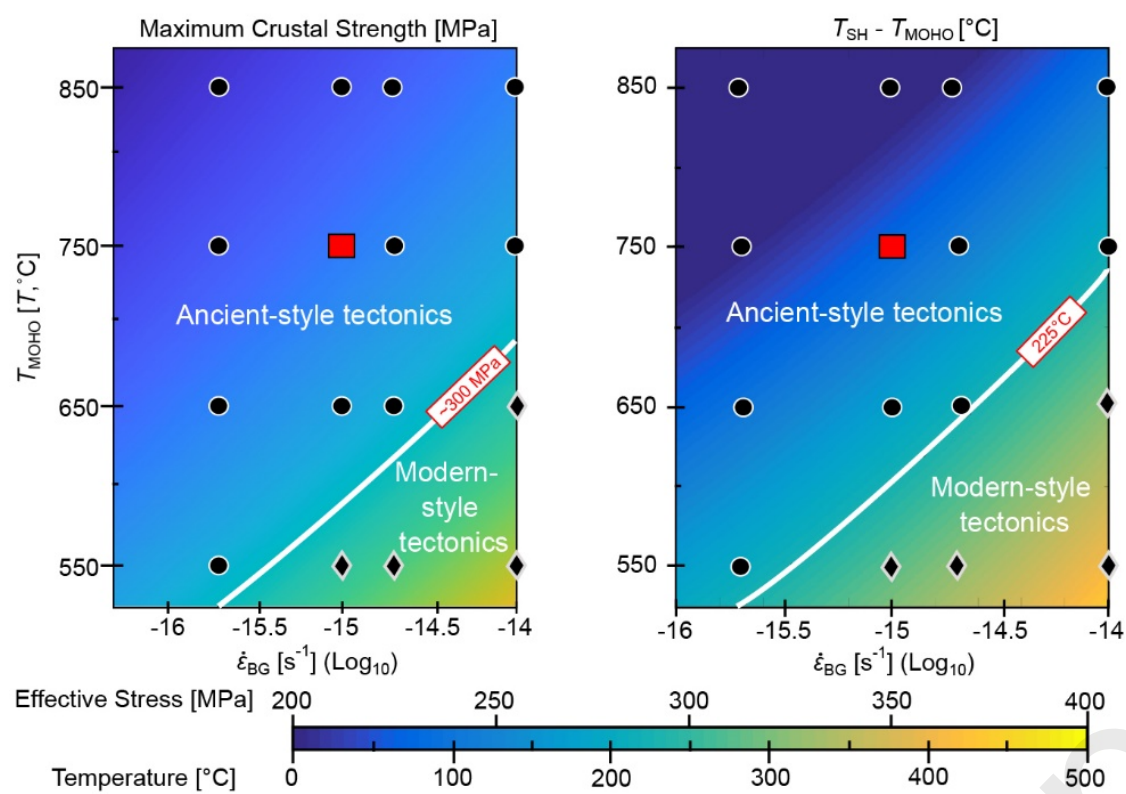


\section{Research Highlights}

- The magnitude of the crustal shear stress dictates the tectonic style.

- Modern style tectonics occurs for a maximum crustal shear stress $>300 \mathrm{MPa}$.

- Shear heating is a key factor for strain localisation in modern style tectonics. 


\section{CRediT author statement for Gondwana Research Submission}

Jonathan Poh: Conceptualisation, Methodology, Investigation, Writing - Original Draft, Writing -Review \& Editing.

Philippe Yamato: Supervision, Software, Resources, Writing - Review \& Editing, Conceptualisation, Validation, Data Curation, Visualisation

Thibault Duretz: Software, Validation, Methodology, Writing - Review \& Editing, Investigation, Data Curation, Visualisation

Denis Gapais: Conceptualisation, Validation.

Patrick Ledru: Validation, Funding acquisition, Writing - Review \& Editing 
Each named author has substantially contributed to conducting the underlying research and drafting this manuscript. Additionally, to the best of our knowledge, the named authors have no conflict of interest, financial or otherwise.

Yours sincerely,

Dr. Jonathan Poh and co-authors

\section{Corresponding Author}

Dr. Jonathan Poh

Energy Research Institute @ NTU,

Nanyang Technological University,

CleanTech One, 1 Cleantech Loop, \#06-04, 637141, Singapore

jonathanpoh87@gmail.com

\section{Additional Contact}

Professor Philippe Yamato

Géosciences Rennes (UMR CNRS 6118)

University of Rennes 1 - Campus Beaulieu CS 74205, F-35042 Rennes Cedex France

philippe.yamato@univ-rennes1.fr 